\title{
A telepoética em Carrossel (SBT): narrativa e estilo na ficção seriada infantojuvenil ${ }^{1234}$
}

Telepoetics in Carrossel (SBT): narrative and style in the infant-juvenile serial ficction

João Paulo Hergesel - Universidade de Sorocaba | Sorocaba | SP | Brasil | E-mail: jp_hergesel@hotmail.com

Resumo: A telepoética é entendida como o modo de criação de produtos televisivos, a partir de suas temáticas, narrativas e estilo. Dentro desse escopo, uma vertente que tem despertado a atenção é a telepoética infantojuvenil, isto é, como são desenvolvidas as obras de ficção televisiva destinadas a crianças e adolescentes. O objetivo geral deste artigo é ampliar as discussões sobre telepoética, sobretudo no âmbito do audiovisual infantojuvenil, a partir de uma abordagem que unifica procedimentos narrativos e traços estilísticos. Para isso, analisa-se, neste trabalho, um conjunto de cenas que compõem a matriz melodramática da telenovela Carrossel (SBT, 2012-2013). A metodologia adotada envolve a análise narrativa a estilística, ancorada em autores como Jean-Marie Thomasseau, David Bordwell e Simone Maria Rocha. Os resultados apontam que a telepoética do SBT, despertada na referida obra, dispõe de uma narrativa calcada no melodrama clássico e um estilo fomentado por exageros e pleonasmos.

Palavras-chave: Audiovisual. Televisão. Narrativa. Estilo. SBT.

Abstract: Telepoetics is understood as the way of creating television products, based on their themes, narratives and style. Within this scope, one aspect that has awakened the attention is the infant-juvenile telepoetics, that is to say, as the works of television fiction are developed for children and adolescents. The general objective of this article is to broaden the discussions about telepoetics, especially in the field of the children's audiovisual, from an approach that unifies narrative procedures and stylistic traits. For this, we analyze, in this work, a set of scenes that compose the melodramatic matrix of the telenovela Carrossel (SBT, 2012-2013). The methodology adopted involves narrative analysis of stylistics, anchored in authors such as Jean-Marie Thomasseau, David Bordwell and Simone Maria Rocha. The results indicate that SBT's telepoetics, awakened in the work analyzed, has a narrative based on classical melodrama and a style fomented by exaggerations and pleonasms.

Keywords: Audiovisual. Television. Narrative. Style. SBT.

${ }^{1}$ O presente trabalho foi realizado com apoio da Coordenação de Aperfeiçoamento de Pessoal de Nível Superior - Brasil (CAPES) - Código de Financiamento 001.

2 Artigo derivado de recorte da tese de doutorado A televisão brasileira em ritmo de festa: a telepoética nas produções do SBT, defendida em 12 de abril de 2019, junto ao Programa de Pós-Graduação em Comunicação da Universidade Anhembi Morumbi (UAM).

${ }^{3}$ Este artigo surge de uma compilação de estudos antecessores (v. HERGESEL, 2017; HERGESEL; FERRARAZ, 2017), de forma revista e atualizada.

${ }^{4}$ As imagens utilizadas neste trabalho respeitam o artigo 46, do Capítulo IV, da legislação sobre direitos autorais (Lei n. ${ }^{9}$ 9.610, de 19 de fevereiro de 1998): "Não constitui ofensa aos direitos autorais: [...] a citação em livros, jornais, revistas ou qualquer outro meio de comunicação, de passagens de qualquer obra, para fins de estudo, crítica ou polêmica, na medida justificada para o fim a atingir, indicando-se o nome do autor e a origem da obra". Todos os direitos são mantidos ao SBT.

- Recebido em 25 de abril de 2019 • Aprovado em 01 de julho de 2019 • e-ISSN: 2177-5788

DOI: https://doi.org/10.22484/2177-5788.2019v45n1p161-191

Copyright @ 2019. Conteúdo de acesso aberto, distribuído sob os termos da Licença Internaonal da CreativeCommons - CC BY-NC-SA - Atribuição Não Comercial (https://br.creativecommons.org/licencas/) Permite distribuição e reprodução, desde que atribuam os devido créditos à publicação, ao autor(es) e que licenciem as novas criações sob termos idênticos. 


\section{Introdução}

A telepoética - também denominada poética televisiva, poética televisual ou poética da televisão - é entendida como o modo de criação de produtos televisivos, a partir de suas temáticas, narrativas e estilo, conforme Butler (2010). Os estudos de telepoética são fundamentais para entender não somente como se moldam as estruturas narrativas e como se compõem as marcas estilísticas de uma produtora/emissora, mas também para ajudar a contextualizar a obra e seu criador nos cenários sociais e culturais.

Dentro desse escopo, uma vertente que tem despertado a atenção é a telepoética infantojuvenil, isto é, como são desenvolvidas as obras de ficção televisiva destinadas a crianças e adolescentes. Para que se possa iniciar uma reflexão sobre o assunto, este trabalho selecionou a telenovela Carrossel (SBT, 2012-2013) como corpus, aplicando a suas cenas uma análise narrativa e estilística.

A título de esclarecimento, conforme Todorov (1973), entendemos narrativa como sendo a obra composta por enredo, personagens, tempo e espaço, geralmente estabelecida por exposição, conflito, clímax e desfecho; e entendemos estilo, segundo Bally (1905; 1909), como a combinação de características prioritariamente verbais [figuras de linguagem], com elementos audiovisuais, segundo Bordwell (2008); Butler (2002), [utilização da câmera, mise-en-scène e trilha sonora] e suas representações sociais, segundo Rocha (2016).

O objetivo geral é ampliar as discussões sobre telepoética, sobretudo no âmbito do audiovisual infantojuvenil, a partir de uma abordagem que unifica procedimentos narrativos e traços estilísticos. Já entre os objetivos específicos estão: recuperar as noções de análise narrativa/estilística aplicada a um produto audiovisual; aprofundar o conhecimento acerca da ficção seriada televisiva infantojuvenil em suas contribuições comunicacionais e culturais; e descobrir quais são os traços mais marcantes na composição áudio-verbo-visual de uma dessas obras.

A metodologia adotada mescla a pesquisa bibliográfica com a analítica, ancorada em autores como Thomasseau (2012), Bordwell (2008) e Rocha (2016). O processo metodológico parte de uma observação atenta do corpus, a partir de oito segmentos do melodrama clássico5, que priorizam: (1) estabelecimento de par romântico; (2) demonstração de conflito familiar; (3) representação de conflito social; (4) momento fatídico; (5) menção a algum elemento nacional; (6) referência a algum fator da

\footnotetext{
5 Para uma revisão detalhada sobre o histórico e as características gerais do melodrama, recomenda-se a leitura de trabalhos anteriores (HERGESEL, 2017; HERGESEL; FERRARAZ, 2017).
} 
identidade da emissora; (7) situação em que a música conduz a história; (8) registro de imagem emblemática.

\section{Narrativa e estilo em Carrossel}

Com autoria assinada por Íris Abravanel e direção geral de Reynaldo Boury, Carrossel foi exibida ao longo de 14 meses, de maio de 2012 a julho de 2013, contando com 310 capítulos, posteriormente reprisados (em 2013, em 2015/2016 e em 2018/2019). Trata-se de uma releitura de Carrusel (México: Televisa, 1989-1990), que por sua vez foi uma versão de Jacinta Pichimahuida, La maestra que no se olvida (Argentina: Canal 9, 1966), a qual teve como base histórias de Abel Santa Cruz (1915-1995), publicadas originalmente nos anos 1940.

A narrativa registra o dia a dia de uma turma de 3.0 ano do Ensino Fundamental, cuja professora é marcante pelo carisma. Embora exista uma concentração no casal infantil protagonista, Cirilo e Maria Joaquina (as tentativas de aproximação, os conflitos interpessoais), as demais crianças - e também os personagens adultos - têm histórias próprias, o que permite a existência de diversos eixos narrativos.

\section{Sintetização do Enredo}

Com o fim das férias escolares, as crianças estão ansiosas para o início das aulas no $3 .^{\circ}$ ano do Ensino Fundamental. Helena, a nova professora, mostra-se nervosa com o desafio de lecionar para a turma, mas acredita em métodos lúdicos para ensinar, ao contrário do que a diretora da escola defende: uma abordagem autoritária e disciplinar. Cada aluno tem uma personalidade, que vai do mais tímido ao mais peralta, demonstrando a diversidade com a qual Helena lidará ao longo do ano letivo.

Ao conhecer seus alunos, Helena traça os problemas com os quais precisará lidar: a garota rica e mimada que menospreza os colegas com base na classe social e na etnia; o garoto que não tem limite com as traquinagens e prejudica os colegas e os outros professores; a garota ingênua que fica submissa às ordens do irmão mais velho; o garoto inocente que é constantemente ridicularizado pelos colegas; a garota com obesidade que sofre bullying devido ao seu peso; dentre outros casos particulares que são desvencilhados ao longo da narrativa.

Por se tratar de uma obra audiovisual dividida em 310 capítulos e com várias linhas de enredo, há diversos pequenos clímaces no decorrer da narrativa. Destaca-se, no entanto, a última tentativa fracassada de Suzana, a professora substituta, de separar Helena e Renê, o professor de música. Com as crianças apoiando o romance de Helena e Renê, o professor recebe ajuda para pedi-la em casamento. O ponto forte se encerra com a cena de casamento dos dois.

O fechamento da narrativa é feito em três níveis: diegético, intradiegético e extratextual. No primeiro caso, as crianças se despedem de 
Helena e Renê, que entram em lua-de-mel, e passa o tempo equivalente à chegada de um novo ano letivo, com os alunos novamente na escola. No segundo caso, um sonho de Adriano, o aluno mais imaginativo, mostra qual será o futuro de cada personagem, como um epílogo em forma de flashforward. No terceiro caso, há um show com todo o elenco no Circo Tihany, evento que de fato aconteceu em São Paulo, em 11 de março de 2013, sendo posteriormente televisionado como parte do capítulo final.

\section{Anotações Prévias sobre a Novela}

De maneira geral, o primeiro elemento que comumente chama a atenção em uma obra, independentemente da plataforma em que é veiculada, é o título. Ao estudar o melodrama, quando do seu surgimento, Thomasseau (2012, p. 32) explica que eles "traziam em seu título o nome do herói $[. .$.$] , da heroína ao patético de sua condição [...], o lugar pitoresco$ ou grandioso onde se desenrolava a ação [...], ou ainda a catástrofe que finalizava o drama". O título Carrossel é, na verdade, uma aglutinação das palavras carro e céu, conforme explicado no episódio 127, de 13 de novembro de 2012. Trata-se do nome da banda que as crianças decidem montar: carro é usado em homenagem a Rafael, pai de Jaime (idealizador do projeto musical), que é mecânico; e céu é utilizado como sinônimo de limite, ou seja, "até onde a banda pode chegar", de acordo com a fala do personagem. A partir dessa análise, verifica-se que esse elemento não dialoga com os critérios inicialmente estabelecidos para o melodrama clássico. No entanto, se for retomado o título da obra original - Jacinta Pichimahuida, La maestra que no se olvida - , é possível verificar a segunda hipótese levantada por Thomasseau: o nome da heroína (Jacinta Pichimahuida) está precedido de sua marca de personalidade (a professora inesquecível).

Prosseguindo nos elementos possivelmente melodramáticos, o tema costuma girar em torno das mesmas ideias: de Providência (a maldade é superada pelas atitudes benévolas), de Reconhecimento (o personagem chega ao ápice de seu desenvolvimento, percebe-se e retorna à estaca zero) e de Amor (as mais variadas formas de condução de uma história amorosa) (THOMASSEAU, 2012, p. 34-38). Em Carrossel, nota-se que, em todas as ações, os atos considerados do mal, embalados em intrigas, fofocas e vilanias, são vencidos pelas ações de bem, permitindo geralmente a abertura para uma lição de moral - atitudes que caracterizam o aspecto da Providência. Já quando há um conflito entre vítima e traidor, principalmente envolvendo as crianças, constata-se que o vilão é reformado e a narrativa volta ao ponto neutro - compondo, portanto, o Reconhecimento. Cenas movimentadas pelo Amor são ainda mais comuns, destacando-se os amores não correspondidos (como a paixão platônica de Cirilo por Maria Joaquina), os triângulos amorosos (especialmente entre os professores Helena, Renê e Suzana), os namoros de infância (tendo como maior referência a afetividade entre Valéria e Davi), as negações do amor 
(tal qual o bloqueio proposital de Paulo pelo que sente por Alicia) e os relacionamentos rompidos (por exemplo, o divórcio de Inês e Frederico).

Não só as relações estabelecidas entre os personagens dialogam com as características como tais seres, em si, têm sua cota de melodramaticidade. Como explica Thomasseau (2012, p. 19), "os personagens do melodrama são personae, máscaras de comportamentos e linguagens fortemente codificadas e imediatamente identificáveis". Tais formas de comportamento ficam tão evidentes a ponto de serem facilmente categorizados. Utilizando o método de classificação de Martín-Barbero (2009, p. 169-170), é possível identificar os traidores, as vítimas, os justiceiros e os bobos.

$\mathrm{Na}$ categoria de Traidor ("personificação do mal e do vício, mas também a do mago e do sedutor"), estão Maria Joaquina, Jorge, Paulo, Kokimoto, Suzana, Matilde e Olívia; na de Vítima ("encarnação da inocência e da virtude, quase sempre mulher"), Cirilo, Carmem, Adriano, Marcelina, Helena e Renê; na de Justiceiro ("que, no último momento, salva a vítima e castiga o traidor"), Daniel, Valéria, Firmino e Mário; na de Bobo ("a presença ativa do cômico"), Jaime, Laura, Graça e Jurandir.

\section{Observando os Recursos Melodramáticos}

Carrossel se inicia com os protagonistas, Cirilo e Maria Joaquina, aprontando-se para o primeiro dia de volta às aulas. Apresenta também a professora Helena, desde sua ansiedade com o novo emprego até o término de sua aula. Para instituir os personagens recorrentes e seus respectivos nomes, a fábula se aproveita da lista de chamada: a cada nome mencionado, a criança levanta a mão e sua imagem é congelada por alguns segundos, junto à aparição de uma legenda com seu nome e figuras relacionadas à sua personalidade -, conforme Oroz (1992), as chamadas imagens simbólicas. Unilaterais, os personagens já assumem previamente a função a que são destinados, segundo Martín-Barbero (2009), posicionando, dentre outros exemplos, Cirilo como vítima, Maria Joaquina como traidora, Daniel como justiceiro e Jaime como cômico - idiossincrasias que se sustentam ao longo da narrativa, algo já apontado na Antiguidade (ARISTÓTELES, 1999).

O enredo é cronológico, o que facilita o acompanhamento, com a exposição inicial necessária (Cirilo é ingênuo; Maria Joaquina é mimada; Valéria é irritadiça; Carmen é humilde; Laura é comilona; etc.) e os conflitos primários (transtornos na aula de música; relação conturbada entre os irmãos Paulo e Marcelina; preconceito racial sofrido por Cirilo), zelando pela introdução da fábula, segundo Thompson (2003), utilizando a lógica das seções da narrativa. A fala da professora Helena ao final do capítulo, "Alguma coisa me diz que ainda tem muito pela frente", dialoga com o formato em questão - a telenovela, que segundo Lopes (2009), cria uma espécie de metalinguagem camuflada, isto é, uma modalidade de expressão falando por si mesma, conforme Martins (2008), uma reflexão de ordem linguística. 
A temporalidade é norteada com a arte gráfica de um sol aparecendo (linguagem visual) e demarcada, em alguns momentos, com o sino da escola (linguagem sonora). A ambientação, por sua vez, é valorizada com o uso de planos de conjunto e enquadramentos abertos em cada primeira cena de um novo cenário, construindo de fato um mundo fictício no imaginário do espectador. Essa estratégia torna visível, por meio da aproximação de ideias opostas, ou seja, uma antítese, segundo Henriques (2011), o contraste estabelecido entre as classes sociais de Cirilo (em um quarto simplório, feliz por ter ganho um estojo) e Maria Joaquina (em um quarto luxuoso, escolhendo a tiara e a mochila que deseja utilizar).

Logo no primeiro capítulo, como pressuposto, é possível notar os quatro pilares da narrativa melodramática, conforme Frome (2014), a saber: par romântico, conflito familiar, conflito social e tragédia ou momento fatídico. O principal casal infantil é apresentado ao som de Fico assim sem você, na voz de Roberta Tiepo, que embarga a cena e tende a fixar a atenção - indo ao encontro da ideia do favorecimento do som pela televisão, segundo Rocha, Alves e Oliveira (2016). Ainda sobre a música, trata-se de um pop romântico de composição de Cacá Moraes e Abdullah e famosa na interpretação de Adriana Calcanhotto. Excerto da letra: "Eu não existo longe de você / e a solidão é meu pior castigo. Eu conto as horas pra poder te ver, / mas o relógio tá de mal comigo".

Maria Joaquina está bastante iluminada mexendo no tablet e recebendo vento no cabelo, enquanto Cirilo se aproxima com expressão anestesiada com a ajuda técnica de um carrinho, numa espécie de travelling de personagem. Corações de arte gráfica brotam sobre a cabeça do garoto, que intercala com Maria Joaquina o foco da mise-en-scène (Figura 1). Fica notável a demonstração do clássico amor à primeira vista, de forma redundante, um pleonasmo, segundo Henriques (2011), juntando a balada romântica, as inserções gráficas e a encenação do personagem. 


\section{Figura 1- Par romântico estabelecido no primeiro capítulo de Carrossel}

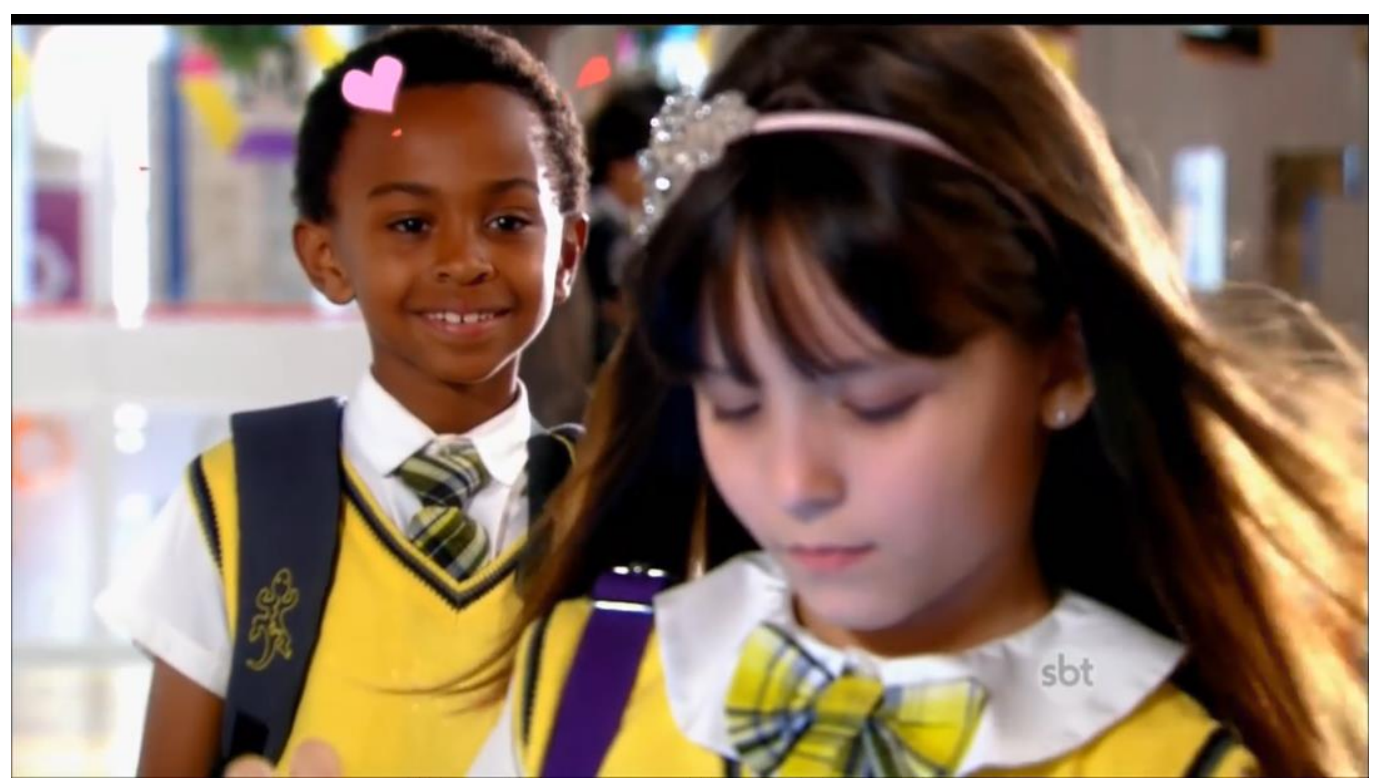

Fonte: Carrossel - capítulo 1. Direção de Reynaldo Boury. São Paulo: SBT, 2012, telev., son., color.

O conflito familiar, que pode ser percebido em algumas cenas, ganha destaque na tristeza do olhar de Inês ao entregar uma maçã como lanche para sua filha. Nessa cena (Figura 2), o enquadramento na casa simples, com um único cômodo unindo sala, quarto e cozinha, já climatiza o drama da pobreza; a maquiagem leve, o penteado caseiro e o figurino bastante simplório endossam essa situação. A pergunta de Carmen, "O lanche está pronto?", é o gatilho para início de uma trilha musical comovente. A fala da mãe, "É uma maçã, filha. É só o que a gente tem hoje", com voz embargada, desperta o sentimentalismo que encontra seu ápice na réplica da garota, "Eu adoro maçã. Obrigada, mãe". A maçã torna-se um símbolo para a falta de dinheiro e, ao mesmo tempo, para a compreensão da criança diante da situação. Em outras palavras, a fruta, acompanhada do gesto, substitui por contiguidade uma explicação acerca do assunto, uma metonímia, segundo Henriques (2011). 


\section{Figura 2 - Conflito familiar estabelecido no primeiro capítulo de Carrossel}

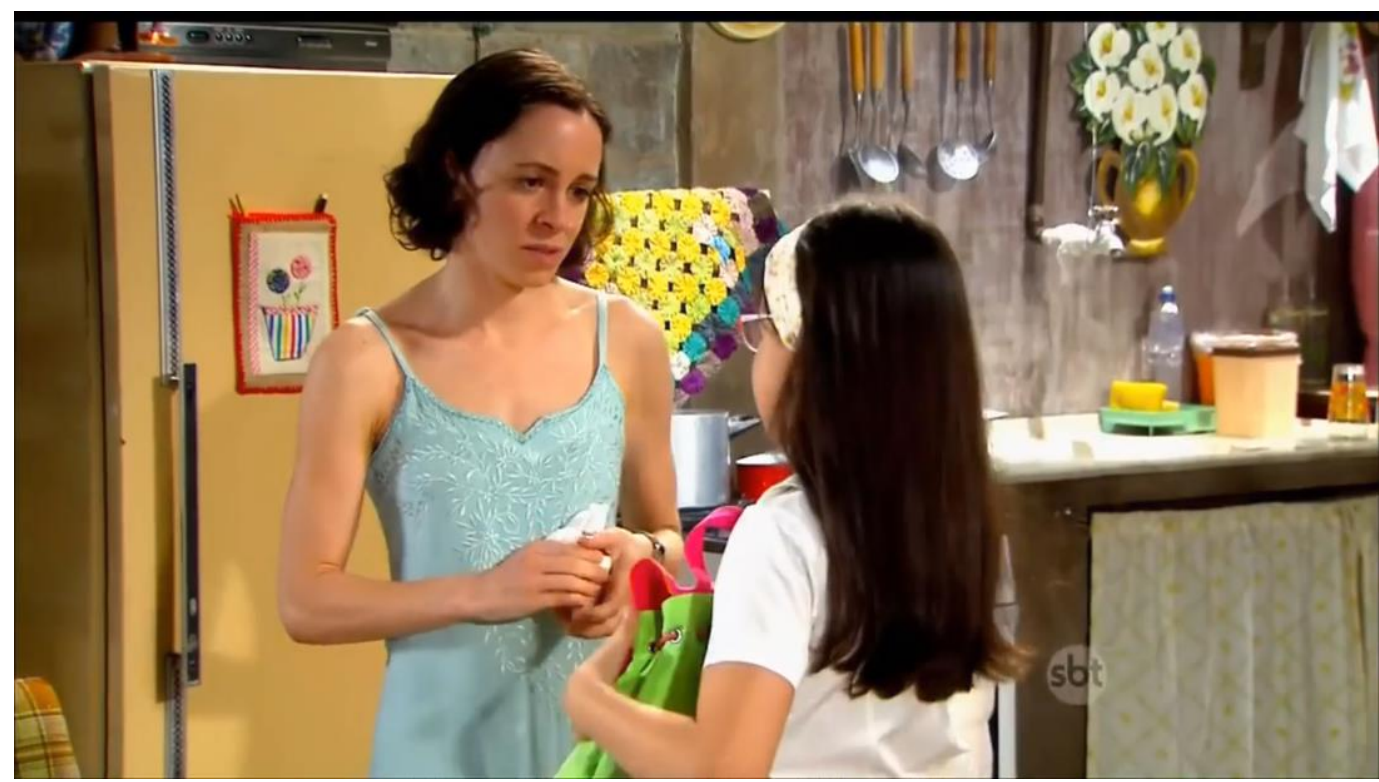

Fonte: Carrossel - capítulo 1. Direção de Reynaldo Boury. São Paulo: SBT, 2012, telev., son., color.

A cena analisada, embora ligada ao vínculo familiar (mãe lamentosa, filha compreensiva) beira o conflito social, que explode nas cenas finais, com o diálogo entre professora Helena e Cirilo, exaltando a relevância do diálogo, conforme Rocha, Alves e Oliveira (2016). Após pisar sem querer no pé de Maria Joaquina, Cirilo é castigado pela professora Matilde e retirado da sala de música. Muito compreensiva, a professora Helena tenta entender o que ocorreu com o garoto, que assume o erro ao dizer que é "um menino muito mau". Daniel aparece para contar a versão justa do fato e, ao se retirar, Cirilo confessa para a professora, em primeiríssimo plano (estratégia aparentemente usada para incentivar uma aproximação visual do espectador): "Eu queria ser amigo da Maria Joaquina, mas ela mal me conhece e já não gosta de mim. Acho que é porque eu sou negro. Por que é que eu tive que nascer negro?". De uma forma didática, a professora explica, ainda em primeiríssimo plano, que não existem cores mais bonitas, que todas são lindas, ao que Cirilo replica: "Mas acho que ela me trata mal também por outra coisa, professora. É que o pai dela é médico, e o meu, apenas um carpinteiro". A professora se utiliza novamente do discurso didático para dizer que o pai dele tem uma profissão maravilhosa e faz uma analogia com o pai do Menino Jesus. Por fim, em um plano de conjunto, o abraço dos dois encerra a cena (Figura 3). 


\section{Figura 3 - Conflito social estabelecido no primeiro capítulo de Carrossel}

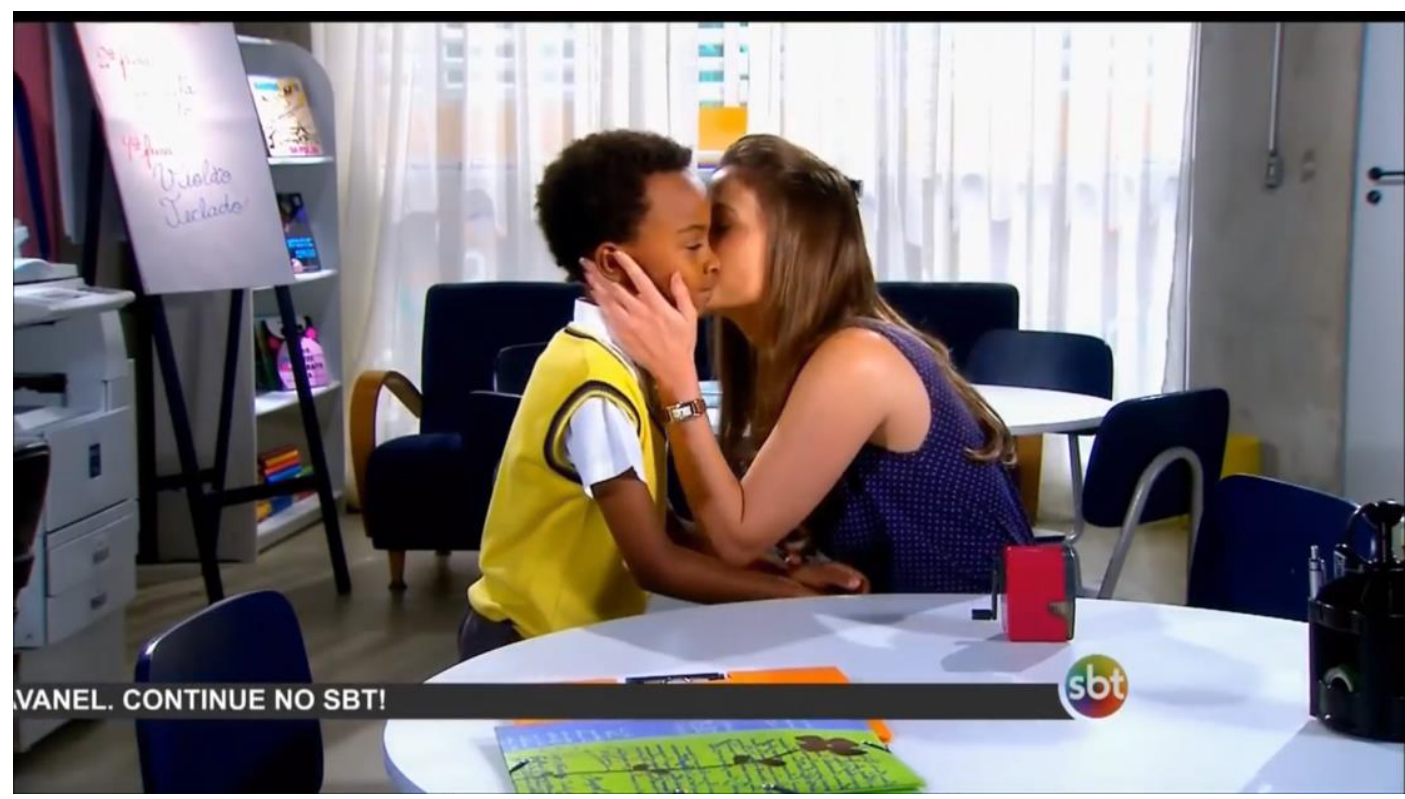

Fonte: Carrossel - capítulo 1. Direção de Reynaldo Boury. São Paulo: SBT, 2012, telev., son., color.

Cirilo protagoniza também o primeiro indício de tragédia da narrativa. Ainda que os acidentes fatais e incidentes prejudiciais ocorram com mais intensidade ao longo da fábula (Helena batendo o carro; a mãe de Maria Joaquina precisando de doação de sangue; a avó de Davi à beira da morte; etc.), o capítulo de estreia traz uma amostragem de heroísmo ou tragédia desviada. Para aprontar com a professora Helena, recém-contratada pela escola, Paulo coloca uma vasilha com farinha de trigo estrategicamente sobre a porta do armário da sala de aula. Quando Helena vai abri-lo e corre o risco de se sujar, Cirilo sai de sua carteira, corre à sua frente e a empurra, fazendo com que o recipiente entorne o conteúdo sobre sua cabeça. A cena (Figura 4) abusa dos planos detalhe (chave, mão no trinco, pote de farinha) e dos primeiros planos (reação da professora assustada e do garoto vitimado), acompanhados de trilha de suspense - capaz de intensificar a ação, denotando uma funcionalidade da música, conforme Oroz (1992) - e do riso coletivo, que involucra a cena de bullying. 
Figura 4 - Tragédia estabelecida no primeiro capítulo de Carrossel

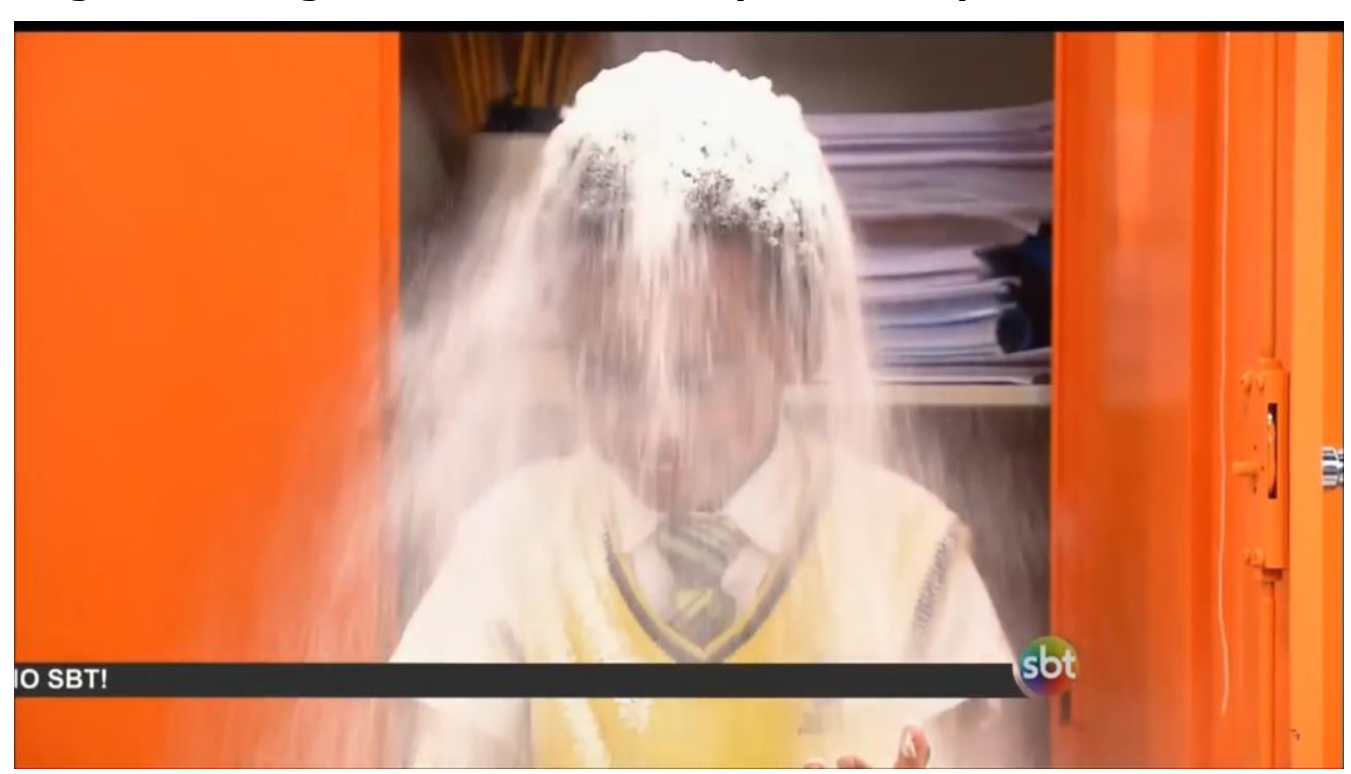

Fonte: Carrossel - capítulo 1. Direção de Reynaldo Boury. São Paulo: SBT, 2012, telev., son., color.

Além dessas características relacionadas ao melodrama nascido no século XVIII, ainda é perceptível a presença de elementos que dialogam com a latinidade, mais especificamente, conforme Oroz (1992). Essa sintaxe é composta por quatro dados narrativos: identidade nacional (há um mapa do Brasil na sala de aula, ao lado do quadro-negro); identidade institucional (Maisa Silva, apresentadora do SBT, assume a interpretação de Valéria; Eliana, também apresentadora da emissora, tem uma canção gravada exclusivamente para a novela); música narrativa (crianças cantando na aula de música; sons enfatizando ações como a queda da farinha de trigo e o pisão no pé de Maria Joaquina); imagens simbólicas (sobretudo as ilustrações junto ao nome de cada personagem no momento da chamada).

Para além desses elementos mencionados, ainda é visível a presença de outras virtudes melodramáticas, segundo Lopes (2009), tais como: a oposição entre homens e mulheres (as meninas voltam-se contra Kokimoto após o garoto ter rabiscado a boneca de Marcelina); o conflito de gerações (Matilde, adulta, não consegue encarar o agito das crianças); a distinção de classes sociais (Maria Joaquina, por ser a mais rica, despreza os demais); e a divisão entre o arcaico e o moderno (o conhecimento didático mais tradicionalista da diretora Olívia em confronto com a neopedagogia adotada pela professora Helena).

Dentre outras possibilidades de análise estilística, é ainda possível mencionar a existência de: figurinos estereotipados (no mecânico Rafael, na diretora Olívia, na servente Graça, no zelador Firmino); uniforme característico de colégios fictícios (com direito a colete e gravata); acessórios chamativos (colar extravagante da professora Matilde, broche gigante na lapela da diretora Olívia, faixa de samurai na testa de Kokimoto, 
luvas de Maria Joaquina); maquiagens marcantes (leve na professora Helena, vibrante na diretora Olívia, evidente em Maria Joaquina, inexistente nas demais mocinhas); linguagem obediente à norma culta da língua portuguesa, com clareza e cadência controlada (sem necessariamente ter a rigidez do nível formal); e aspectos de humor voltados às comédias circenses.

A respeito das dimensões culturais que a narrativa atinge, podemos apontar que as cenas iniciais da novela, contrastando os quartos de Cirilo e Maria Joaquina, que superficialmente indicariam a diferença do nível financeiro de cada personagem, segundo Valentim (2016), podem ser compreendidas como um estímulo visual ao consumo.

Esse mesmo fenômeno pode ser observado na cena que se passa na casa de Carmen. Ainda que a ambientação não vise ao resgate de tendências do contemporâneo, como a localização em favelas ou comunidades modestas, tal como mostram as narrativas naturalistas, a mise-en-scène traz os objetos cenográficos como representação do desfavorecimento financeiro. Paredes sem reboque, torneira amarrada com sacola, geladeira antiga, além dos enfeites de expressão massiva, ou seja, o kitsch, segundo Moles (1975) - como capa de crochê para o fogão, adesivo na parede, ímã de geladeira, guardanapos pintados à mão, etc. são alguns exemplos para simbolizar a simplicidade. Esses aspectos não condizem exclusivamente com a realidade brasileira, mas representam um estereótipo de pobreza no imaginário coletivo - outra característica tipicamente melodramática.

Seguindo esse raciocínio, é justificável a intenção do merchandising que percorre toda a novela, ainda que não demonstre sua força no capítulo de estreia. Como menciona Silva (2016, p. 150), ao discutir a relação entre Comunicação e Consumo, "em vez de produzir cenas com os produtos [...], opta-se estrategicamente por construir cenas a partir das marcas". A pesquisadora expande seu olhar ao afirmar que, além dos produtos infantis, existe uma insistente inserção de marcas destinadas ao público adulto, uma vez que o target do produto engloba não somente os filhos como também os pais, criando a ideia de família como público, segundo Rocha, Alves e Oliveira (2016).

Voltando à pesquisa de Valentim (2016), a figura da professora Helena, sempre meiga e inabalável, é capaz de gerar uma espécie de fetiche: ao mesmo tempo em que os professores da vida real não acreditam em um nível de perfeição docente como o de Helena, admitem querer ser como ela (a cultura ficcional invade a realidade cultural). A pesquisadora ainda informa que algumas pessoas entrevistadas para seu trabalho confessaram ter optado pelo magistério após assistirem à telenovela e se identificarem com o modo familiar e compreensivo com o qual Helena trata seus alunos. Por mais que seja inverossímil, existe certa paixão despertada no espectador que o faz aceitar essa invenção romântica como fenômeno convincente - fato apontado na Poética aristotélica, conforme Aristóteles (1999). 
No primeiro contato de Cirilo com Maria Joaquina, é possível perceber que a maquiagem no rosto da garota enfatizou sua palidez, enquanto a iluminação destinada ao garoto favoreceu o tom de sua pele. Neste ponto, fica clara a distinção racial, segundo Souza (2015), que posteriormente despertará o preconceito na garota (que o esnoba e o maltrata todas as vezes em que ele se aproxima para tentar um diálogo) e causará baixa autoestima no garoto (que confessa à professora Helena sentir-se malquerido pelo fato de ser negro). O preconceito racial, temática já abordada em outras telenovelas nacionais, é um assunto social de nível universal, bastante presente em narrativas melodramáticas, porém pouco discutido quando o assunto é o gênero infantojuvenil. Ao trazer tais cenas para o jovem telespectador, acredita-se na concretização de uma provocativa, um despertar de realidade registrado de forma paradidática, para o que ocorre no contexto sociocultural do mundo.

$\mathrm{Na}$ tentativa de considerar a novela como um todo, para demonstrar que o estilo melodramático não se sustenta apenas no primeiro capítulo, selecionamos mais algumas cenas que dialogam com as diretrizes até aqui estudadas. O recorte eleito para se analisar o estabelecimento do par romântico, agora com o casal adulto, é o primeiro encontro de Renê e Helena, ocorrido no baile de máscaras promovido pela família da Maria Joaquina. Helena está na sala principal e, de repente, Renê entra por uma das portas. O ponto de início da cena é marcado pela música Quem quiser sonhar, na voz de Maria Diniz, com registro em plano médio na figura de Helena mascarada (Figura 5).

O olhar da personagem leva a outro plano: Renê, também fantasiado e enquadrado em plano médio, chegando à sala e com o olhar direcionado à Helena (Figura 6). Conforme vão se aproximando, o efeito de zoom in reduz o enquadramento aos rostos dos personagens. Quando ambos estão próximos, um defronte ao outro, colados à mesa de doces, uma terceira câmera se encarrega de registrá-los em plano de conjunto, deixando à mostra os demais convidados da festa, mais distantes (Figura 7).

Após alguns segundos de estatismo do casal, contrastando com os movimentos dos demais personagens mais atrás, as câmeras voltam a enquadrar, em planos opostos, os rostos conectados pelo olhar. Em dez planos intercalados (ou cinco para evidenciar cada um), o primeiro plano transforma-se em primeiríssimo plano até se finalizar em plano detalhe nos olhos de cada (Figura 8). 
Figura 5 - Professora Helena no baile de máscaras de Maria Joaquina

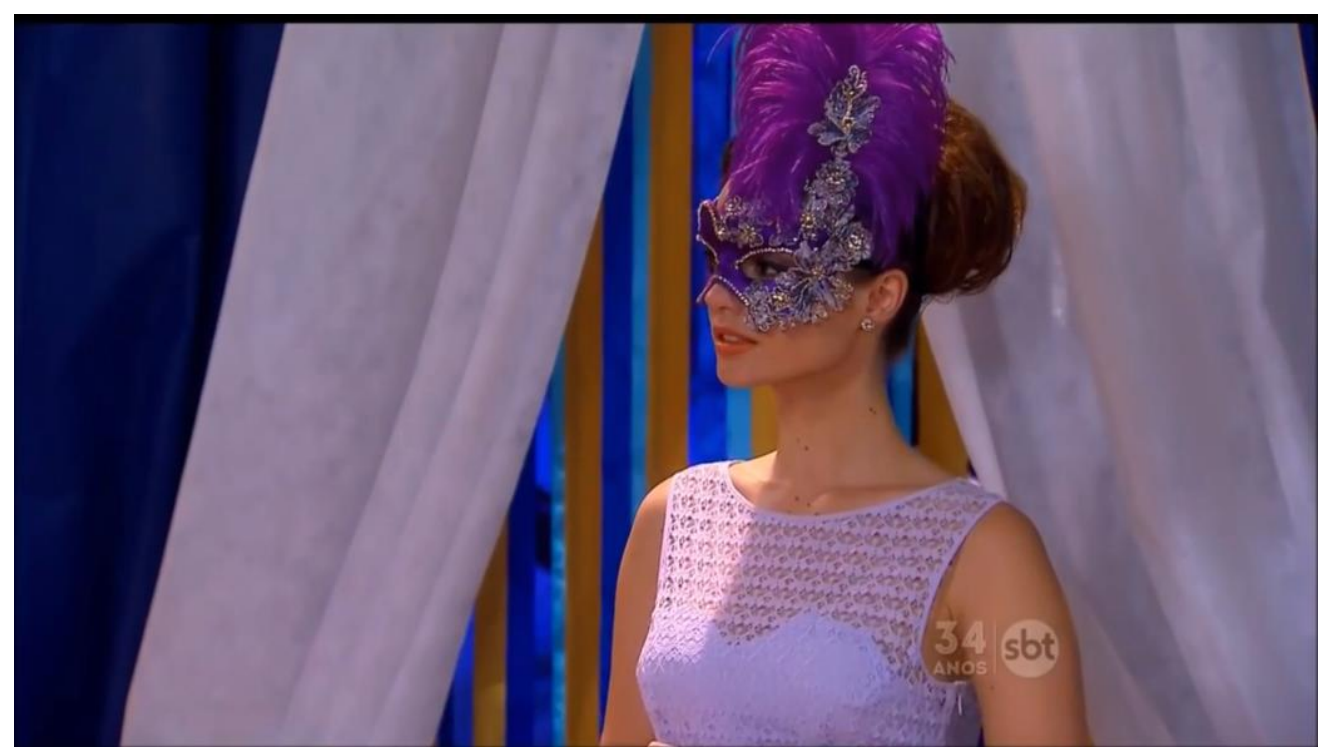

Fonte: Carrossel - capítulo 138. Direção de Reynaldo Boury. São Paulo: SBT, 2012, telev., son., color.

Figura 6 - Professor Renê no baile de máscaras de Maria Joaquina

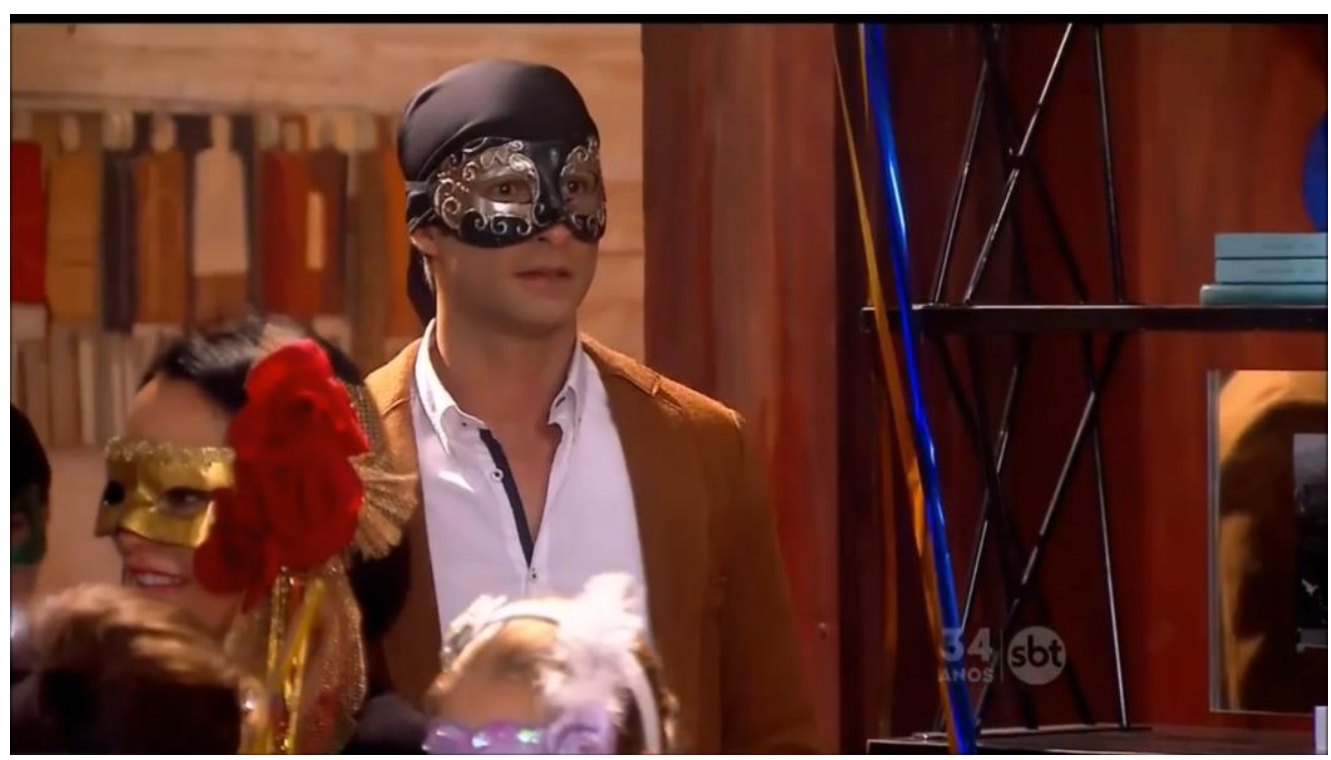

Fonte: Carrossel - capítulo 138. Direção de Reynaldo Boury. São Paulo: SBT, 2012, telev., son., color. 
Figura 7 - Helena e Renê se encontram no baile de máscaras de Maria Joaquina

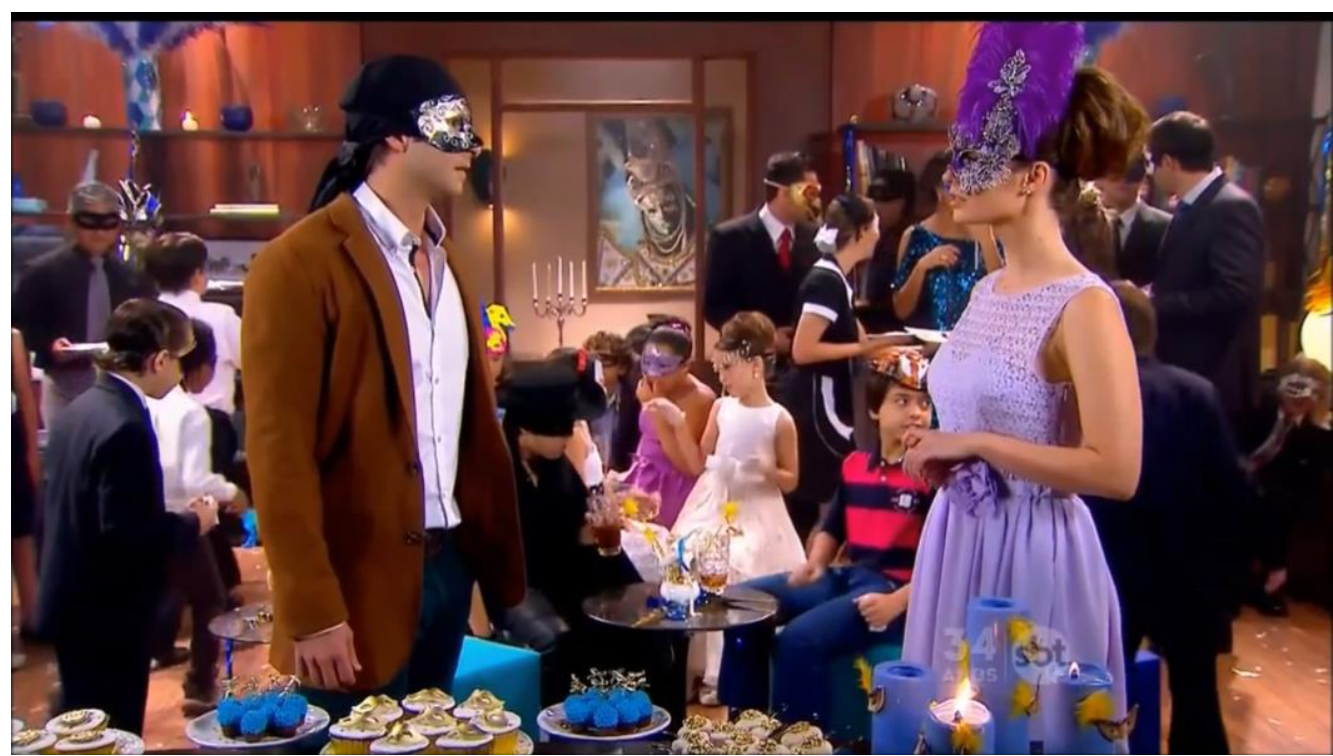

Fonte: Carrossel - capítulo 138. Direção de Reynaldo Boury. São Paulo: SBT, 2012. Telev., son., color.

Figura 8 - Plano detalhe nos olhos de Helena

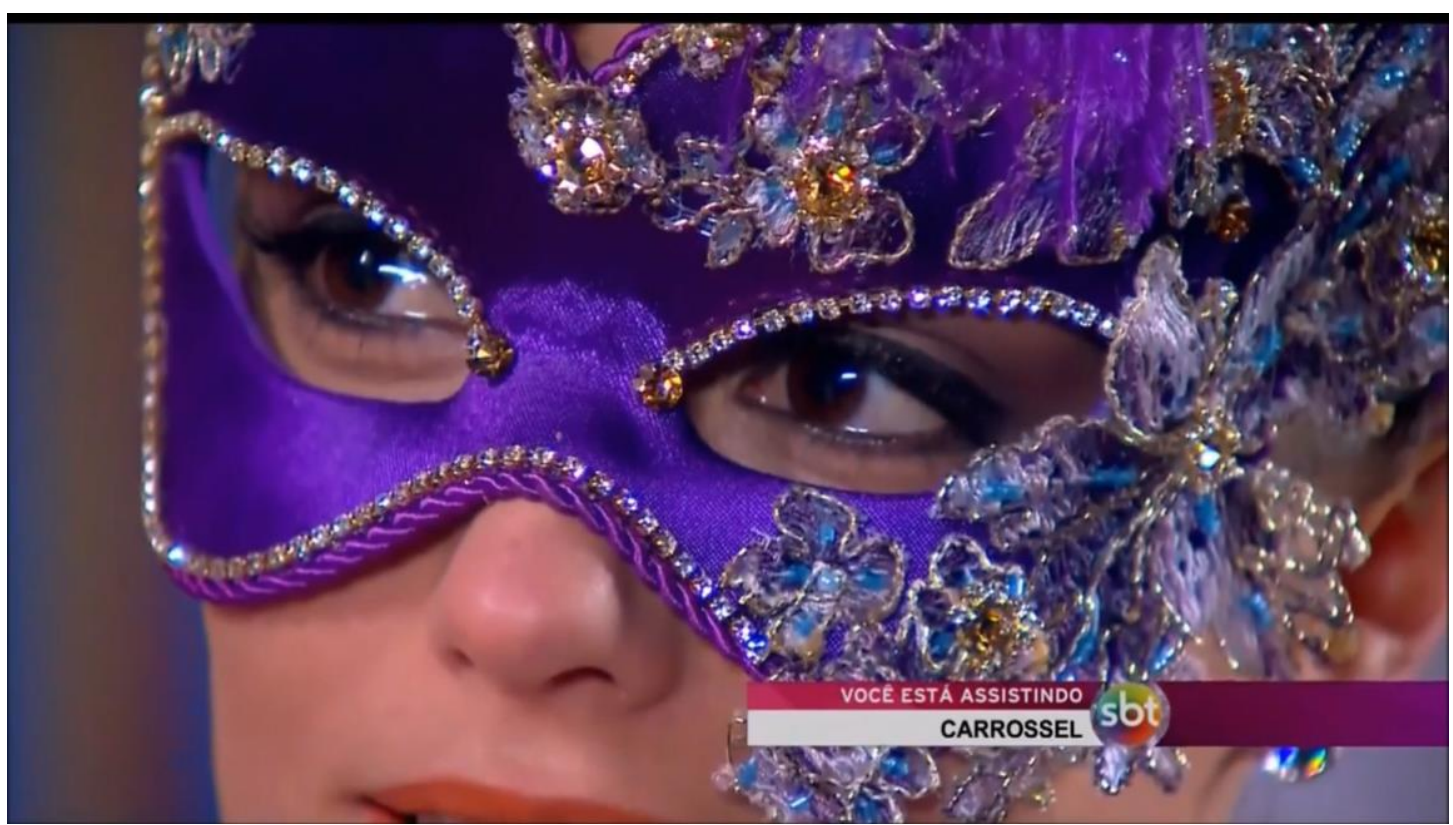

Fonte: Carrossel - capítulo 138. Direção de Reynaldo Boury. São Paulo: SBT, 2012, telev., son., color. 
Fica estabelecido, portanto, sem a necessidade de diálogos ou falas isoladas, nem elementos sonoros complementares à trilha musical, a constituição desse par romântico. Fica também claro o obstáculo a ser enfrentado quando a cena seguinte revela, em corte seco, Suzana limpando seu vestido; sugere-se que ela será a terceira ponta do triângulo amoroso que se desenvolverá até o último capítulo.

A respeito dos conflitos familiares, a cena escolhida para análise é a do momento em que Frederico conta à sua filha, Carmem, que está se separando de Inês. O encontro ocorre na lanchonete, após o pai buscar a menina na escola e levá-la para comer um sanduíche. Assume-se o posicionamento de que espectador já está ciente do conteúdo da conversa, visto que vem sendo preparado desde os capítulos anteriores da novela.

Carmem, enquadrada em primeiro plano junto a um misto quente e um suco de laranja, fala: "Isso é um problema de gente grande. Eu ainda não sou uma mocinha e nem quero ser. Eu não quero crescer com você separado da mamãe" (Figura 9). A garota termina a fala cabisbaixa, com os lábios voltados para baixo e os dedos trançados. Parece admitir não ter coragem de encarar o próprio pai.

Frederico segura as mãos de Carmem, que param de se mexer, e o olhar da menina se dirige a ele no momento em que, já com o foco, tenta amenizar a situação: "Carmem, minha filha, o que eu posso te dizer?" (Figura 10). A garota é direta e objetiva ao responder, com o foco da imagem em si: "Que vocês vão voltar a ficar juntos". O homem desencosta sua mão das mãos da filha, retoma o foco imagético e, após um suspiro, expressa o lamento: "Infelizmente, a gente nem sempre tem o que quer".

Levantando com dois dedos o rosto de Carmem, novamente cabisbaixa, Frederico pede: "Eu queria ver seu sorriso, mas só estou vendo suas lágrimas". Com fala chorosa, Carmem responde, forçando um sorriso molhado pelas lágrimas que escorrem pela face: "Eu te amo, papai. Eu sorrio pra você, se você quiser. Tá vendo?" (Figura 11). A música instrumental, até então, praticamente inaudível, ocupa o espaço e enfatiza a dramaticidade do momento. Segurando novamente as mãos de Carmen e também com os olhos marejados, Frederico olha com compaixão para a filha.

Carmem é registrada em primeiríssimo plano (Figura 12) e a cena se encerra, reforçando o uso desse enquadramento para intensificar o sujeito das ações e o enfoque que o eixo narrativo precisa dar à personagem. Fica notória também a utilização da imagem como acompanhamento da fala, registrando sempre quem está com a vez no diálogo, e da trilha musical como invólucro das ações. A conversa, por sua vez, é direta e sem rodeios, em linguagem clara, ainda que se tratando de uma troca de informações tristes. 
Figura 9 - Carmen cabisbaixa, dividindo o plano com o suco de laranja e o sanduíche

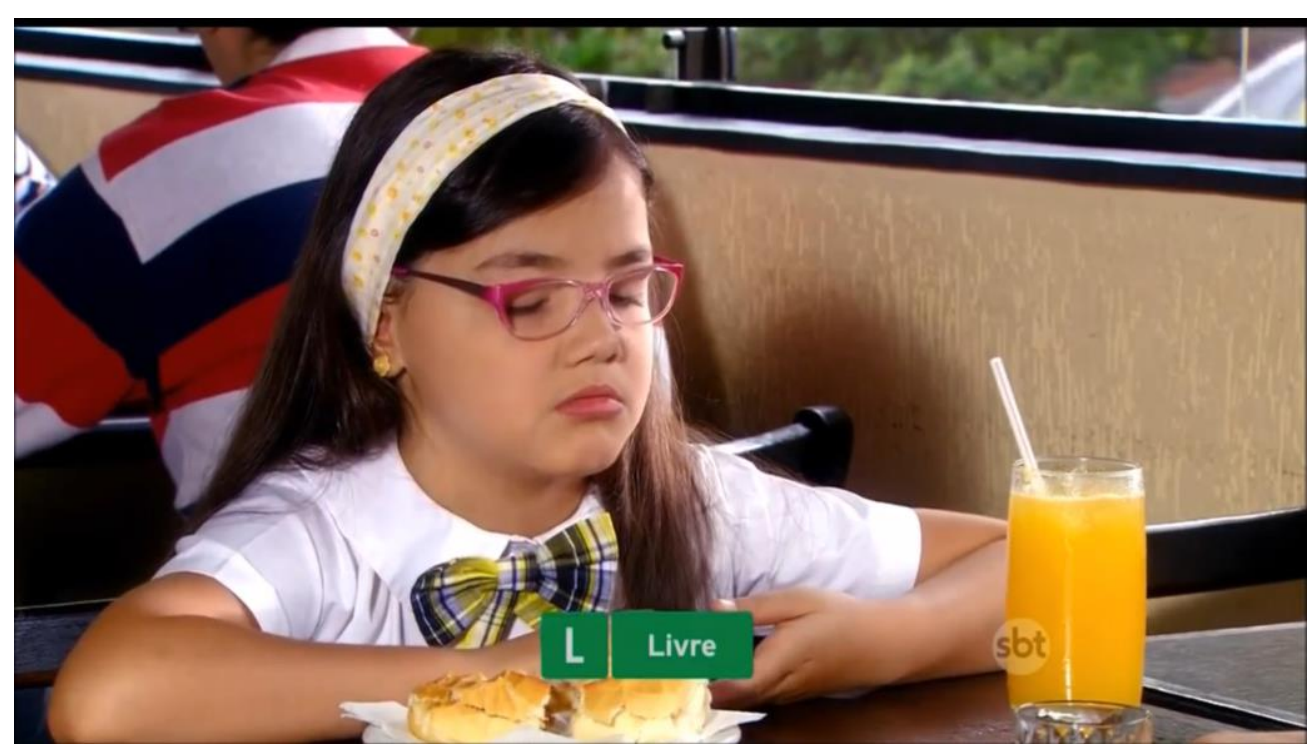

Fonte: Carrossel - capítulo 6. Direção de Reynaldo Boury. São Paulo: SBT, 2012, telev., son., color.

Figura 10 - Frederico tenta consolar a filha

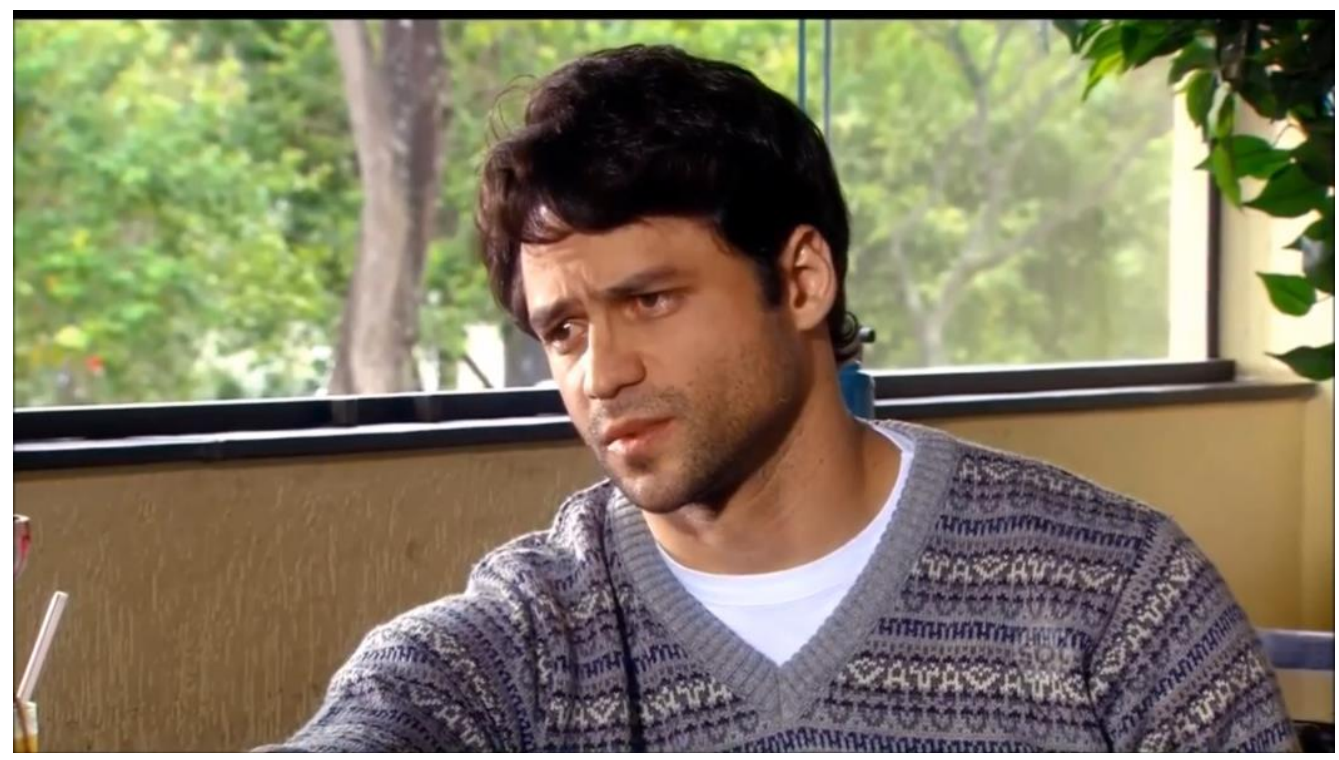

Fonte: Carrossel - capítulo 6. Direção de Reynaldo Boury. São Paulo: SBT, 2012, telev., son., color. 
Figura 11 - Carmen força um sorriso para o pai

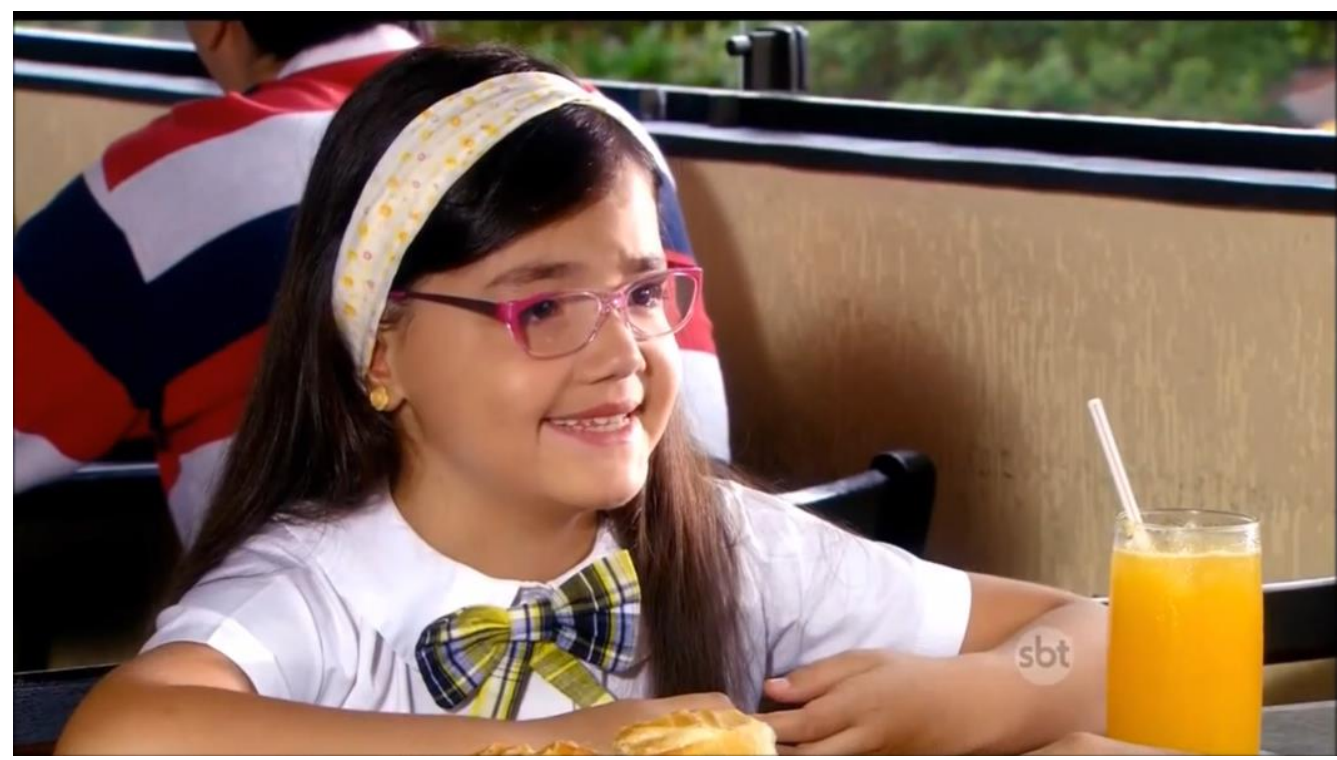

Fonte: Carrossel - capítulo 6. Direção de Reynaldo Boury. São Paulo: SBT, 2012, telev., son., color.

Figura 12 - Carmen é registrada em primeiríssimo plano

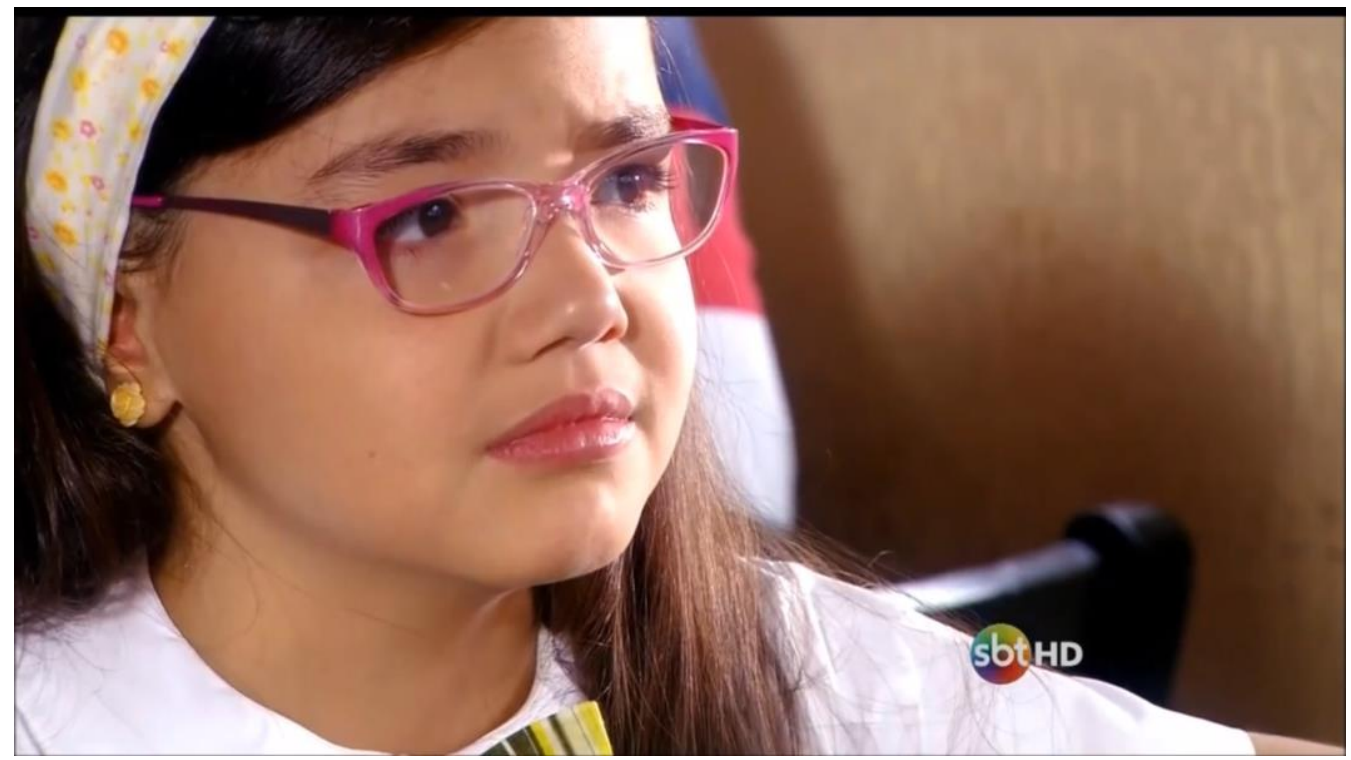

Fonte: Carrossel - capítulo 6. Direção de Reynaldo Boury. São Paulo: SBT, 2012, telev., son., color.

A tristeza também é a emoção mais evidente nos momentos de circunstâncias trágicas. Sobre essa característica, uma das cenas mais trágicas da telenovela foi a do acidente automotivo envolvendo a professora Helena, em seu dia de retorno à escola. Com foco inicial no carro vermelho de Helena rodando pela rua e se aproximando da câmera (Figura 13), temse um corte para o rosto da mulher, que expressa, sorridente: "Hoje vai ser um dia muito especial" (Figura 14). A música que envolve esse momento é tranquila, como uma valsa vienense. 
Em outro plano, surge em cena um carro acelerado, preto, cantando pneus e andando em zigue-zague (Figura 15). Troca-se a música por uma melodia mais sombria, como uma pauta sonora de filmes de ação e aventura. As músicas, no entanto, parecem se fundir num instrumental romântico-trágico quando o carro de Helena é apresentado outra vez, intercalando com a exibição do outro carro.

Quando Helena observa o carro vindo, pela lateral, em sua direção a seu veículo, tira as mãos do volante e as leva ao rosto (Figura 16). Os carros se chocam, com um som intenso de batida, e Helena, mesmo usando cinto de segurança, cai desacordada no banco do passageiro, que está forrado pelas rosas brancas que ganhou antes de sair de casa (Figura 17). A cena se encerra sem diálogos, com a cabeça da mulher sendo amortecida pelas flores, que cumprem, metonimicamente, com a função de travesseiro.

Figura 13 - Carro de Helena

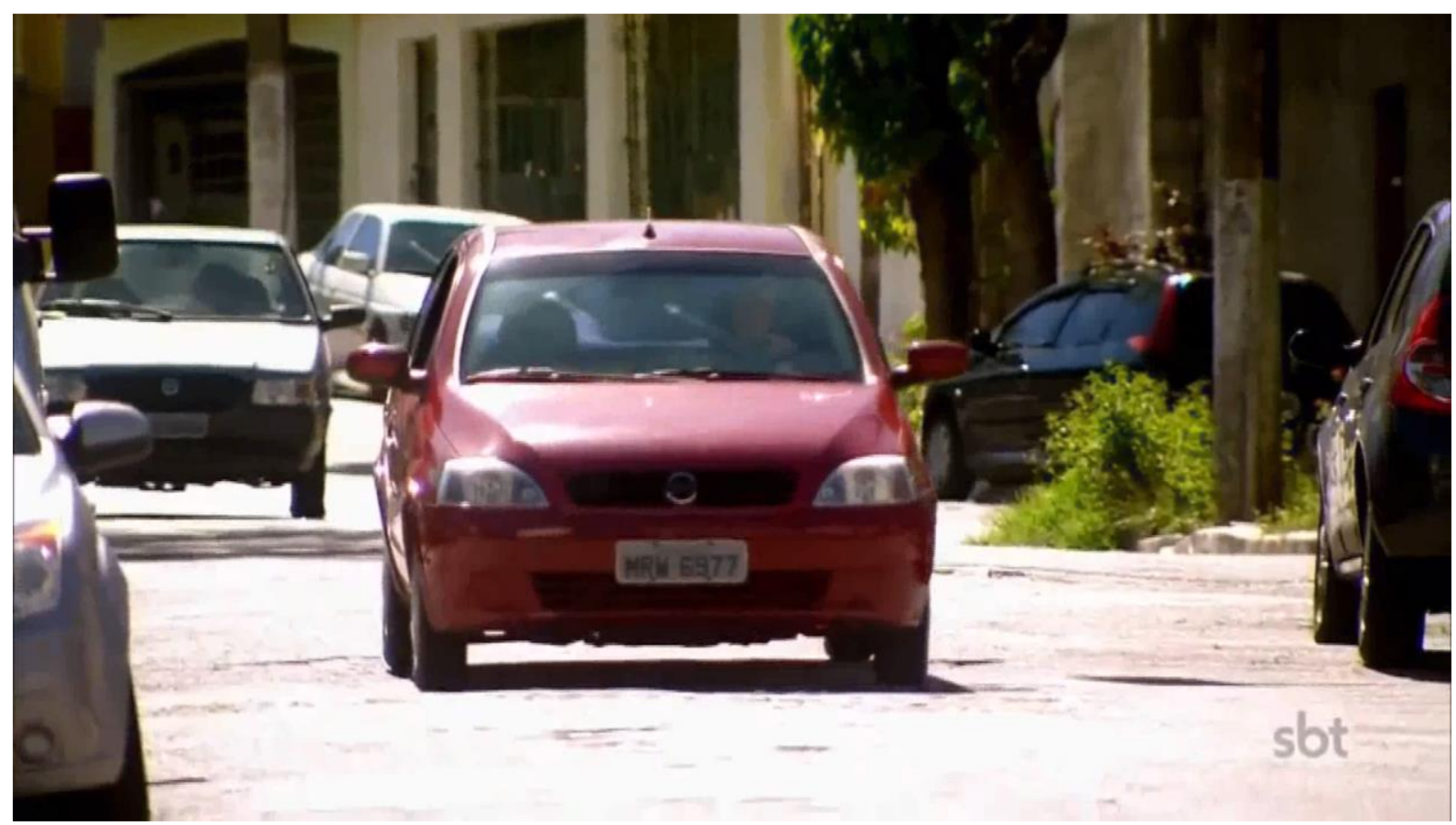

Fonte: Carrossel - capítulo 73. Direção de Reynaldo Boury. São Paulo: SBT, 2012, telev., son., color. 
Figura 14 - Helena demonstra tranquilidade ao dirigir

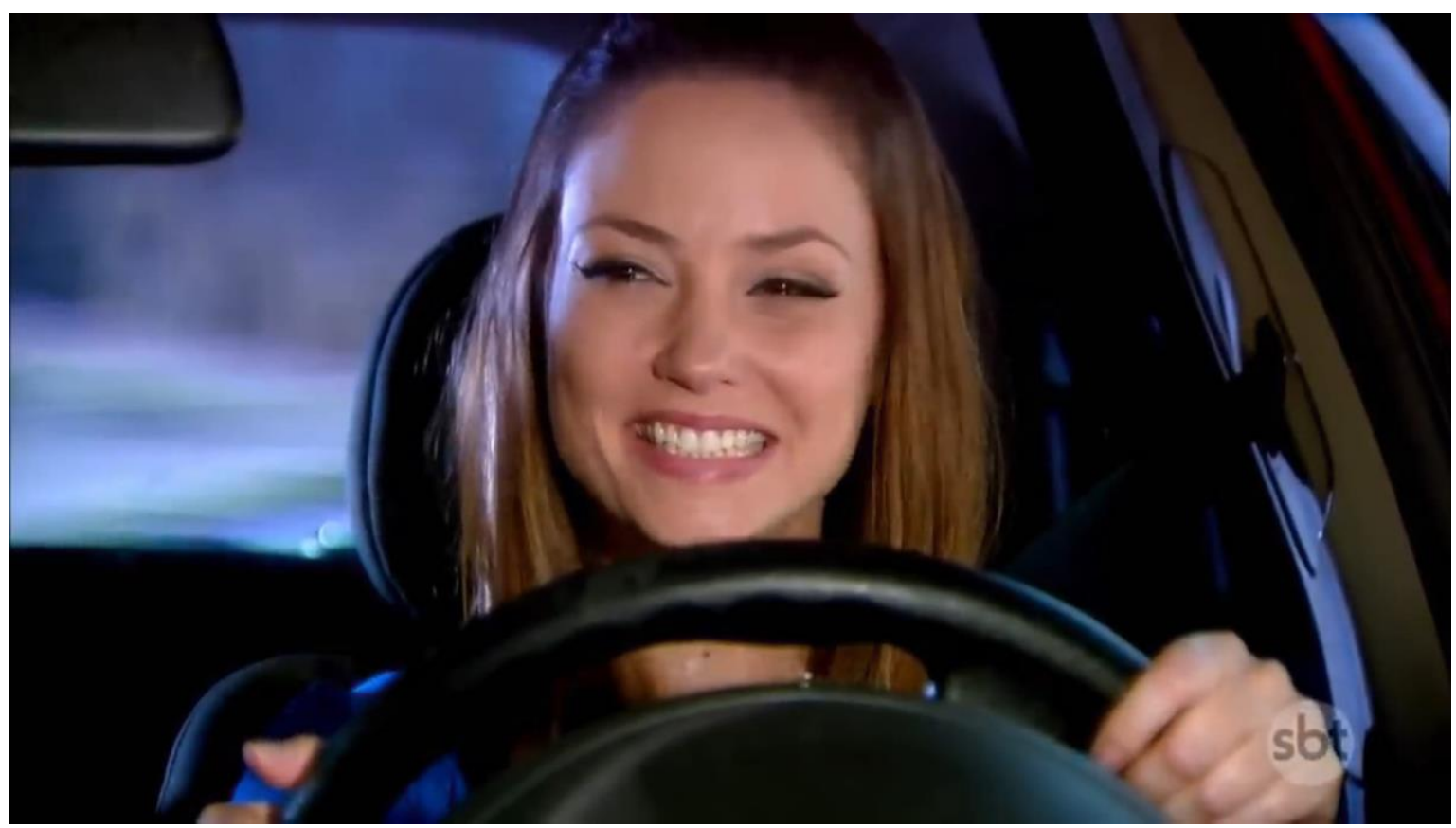

Fonte: Carrossel - capítulo 73. Direção de Reynaldo Boury. São Paulo: SBT, 2012, telev., son., color.

Figura 15 - Carro conduzido por motoristas embriagados

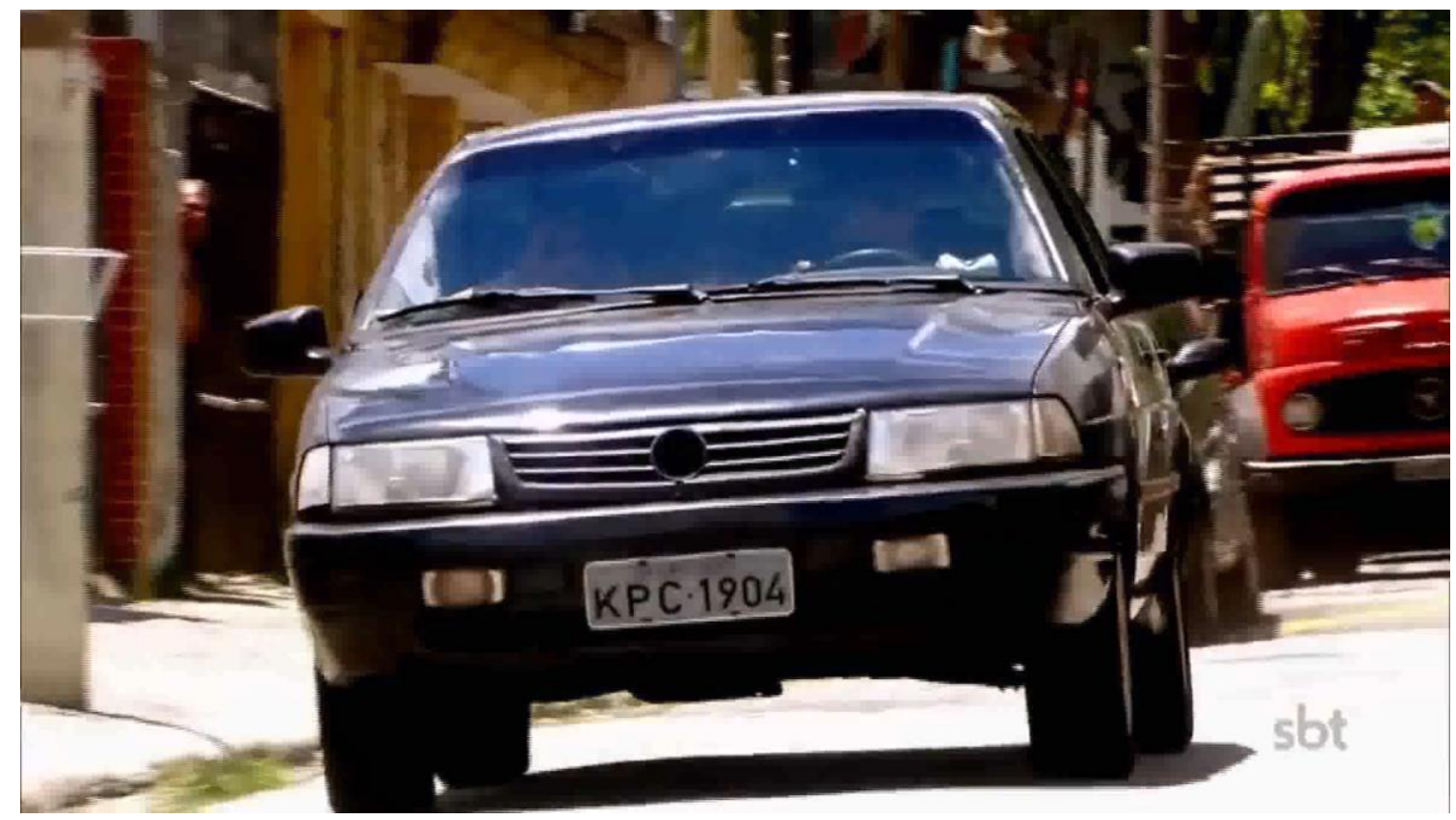

Fonte: Carrossel - capítulo 73. Direção de Reynaldo Boury. São Paulo: SBT, 2012, telev., son., color. 
Figura 16 - Helena tenta proteger-se com os braços

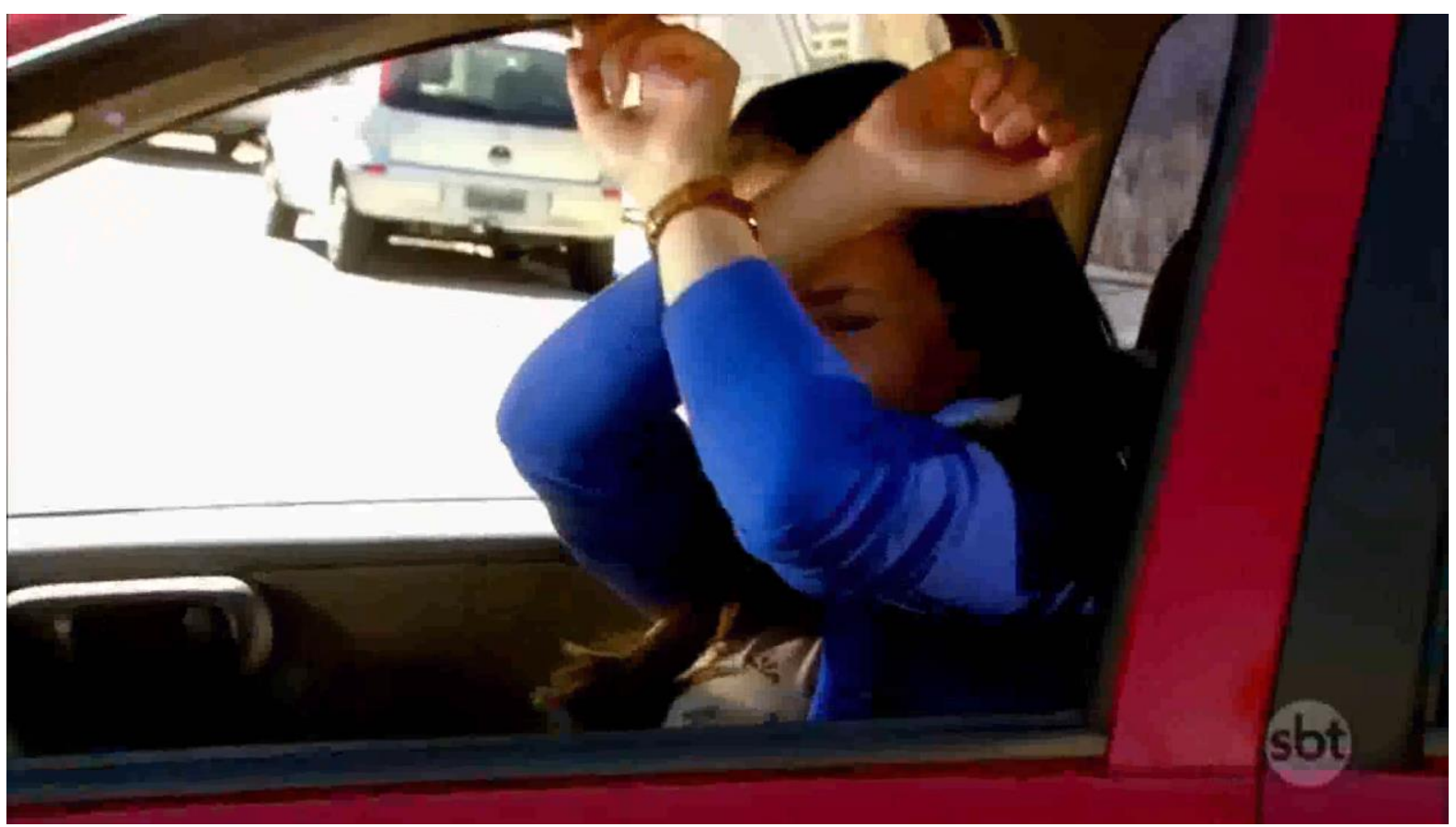

Fonte: Carrossel - capítulo 73. Direção de Reynaldo Boury. São Paulo: SBT, 2012, telev., son., color.

Figura 17 - Helena cai desacordada no banco do passageiro

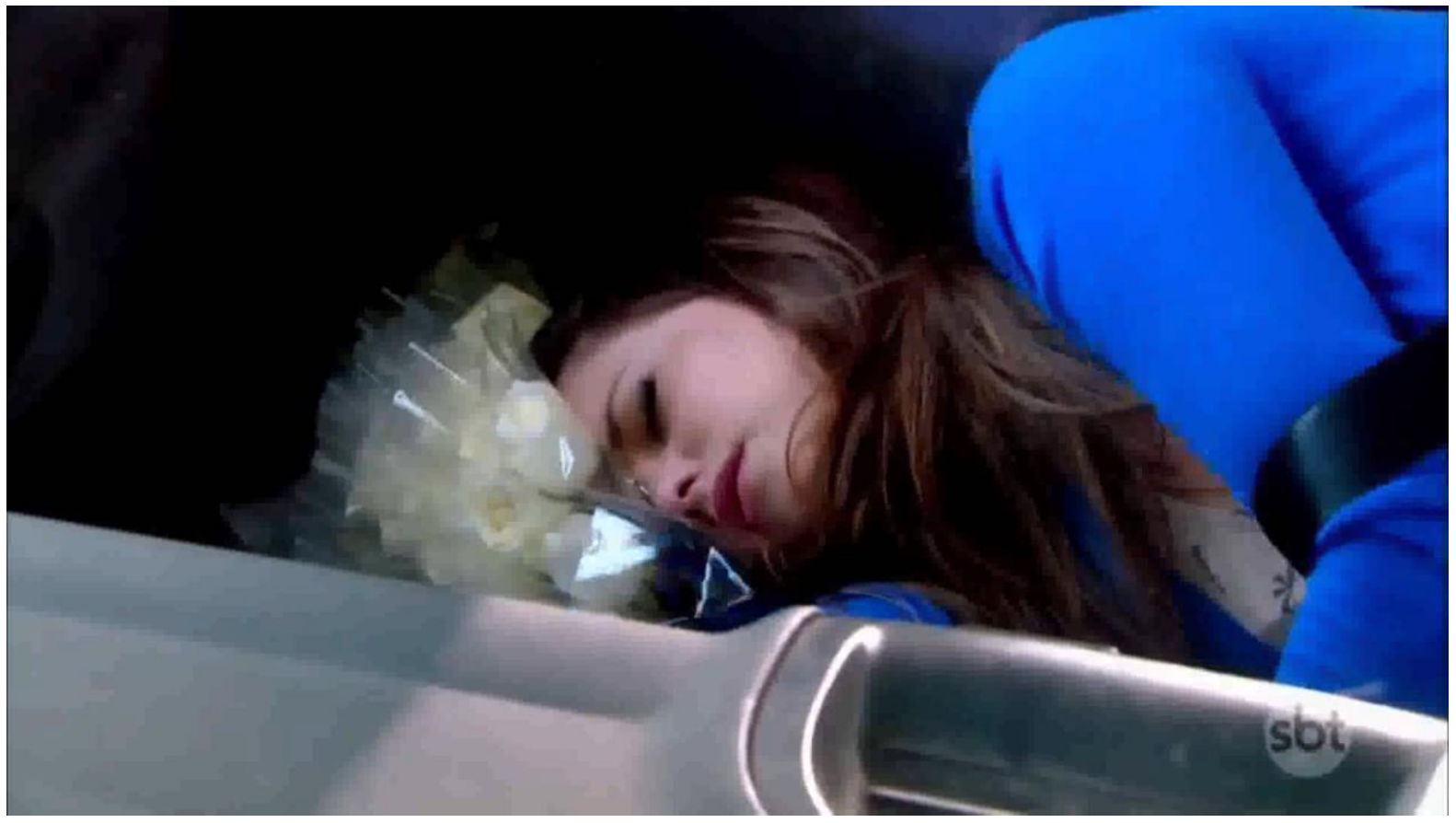

Fonte: Carrossel - capítulo 73. Direção de Reynaldo Boury. São Paulo: SBT, 2012, telev., son., color. 
Não há diálogos na cena, excetuando a fala inicial de Helena, que mais parece ironia se considerado o porvir. Podemos, neste ponto, sugerir até um estudo semântico em relação às cores do carro: vermelho, de Helena, relacionado ao sangue; preto, do motorista embriagado, associado ao luto.

Ainda nas características gerais do melodrama, as preocupações sociais e de classe estão presentes no eixo narrativo principal da telenovela, tendo destaque o relacionamento entre Maria Joaquina e Cirilo. Ele, filho de carpinteiro e costureira, tenta, de todas as formas estreitar o relacionamento de amizade com ela; já ela, filha de médico e socialite, recusa de todas as formas a aproximação do garoto, levando em consideração sua classe social e o fato de ele ser afrodescendente.

A alusão ao preconceito fica exacerbadamente evidente no capítulo em que Maria Joaquina convida os colegas para sua festa de aniversário e exclui Cirilo de sua lista de convidados. Na cena em que Daniel vai conversar com ela, sugerindo que ela dê um convite a Cirilo, ela é objetiva ao dizer, em primeiro plano, sem desgrudar o olhar do tablet que segura nas mãos: "Uma pessoa como o Cirilo nunca vai entrar na minha festa" (Figura 18).

O primeiro plano vai para Daniel, que faz uma expressão indagativa e questiona: "O que você quer dizer com 'uma pessoa como o Cirilo'?" (Figura 19), desejando supostamente que a garota reflita acerca da perífrase utilizada para denominar o colega afrodescendente. Ela ignora, mantendo o olhar na tela do equipamento eletrônico, e Daniel prossegue: "Você tem que parar de tratar o Cirilo assim. Ele é gente como a gente". Ainda sem modificar o direcionamento do olhar, ela rebate: "Não, ele é bem diferente da gente, Daniel". 


\section{Figura 18 - Maria Joaquina demonstra frieza ao falar sobre Cirilo}

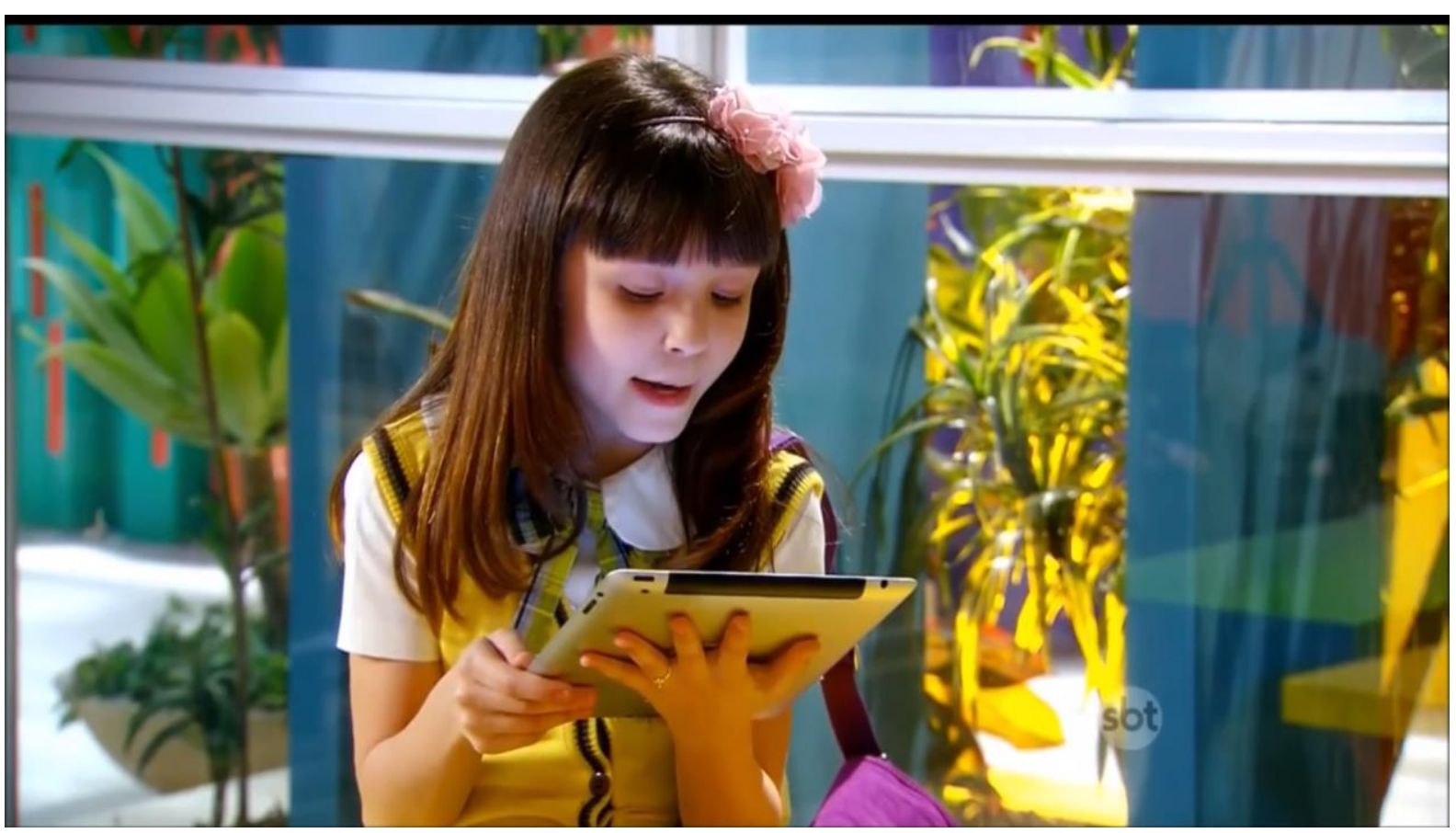

Fonte: Carrossel - capítulo 8. Direção de Reynaldo Boury. São Paulo: SBT, 2012, telev., son., color.

Figura 19 - Daniel mostra-se incrédulo durante a conversa com Maria Joaquina

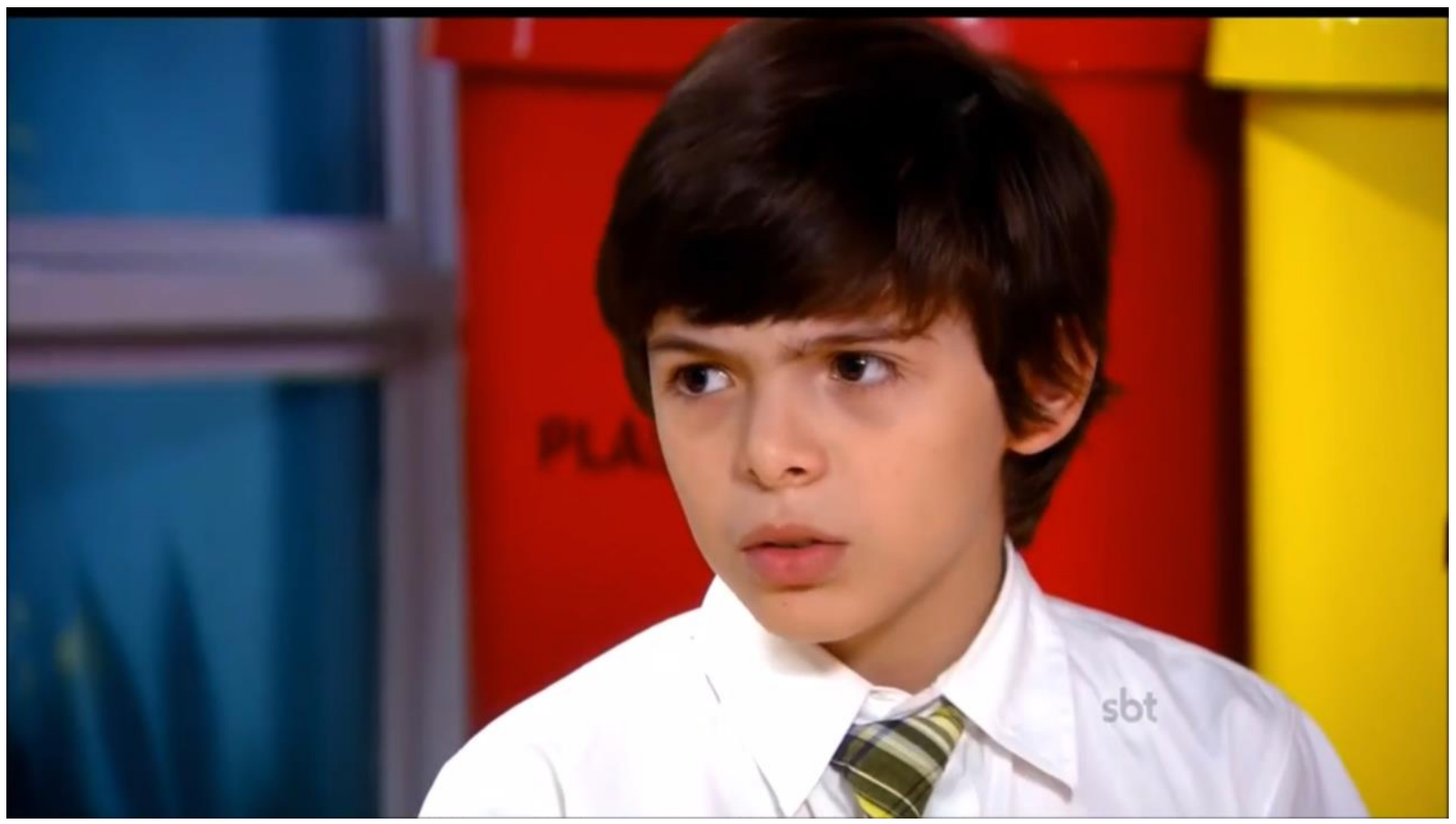

Fonte: Carrossel - capítulo 8. Direção de Reynaldo Boury. São Paulo: SBT, 2012, telev., son., color. 
Daniel faz suas considerações, invocando a divindade em sua fala: "Maria Joaquina, acho que você não tem coração. Deus tá vendo, viu?". Em sua defesa, Maria Joaquina finalmente levanta o olhar e encara Daniel com a afirmativa: "Ah, por favor, né, Daniel... Deus tem coisa mais importante para fazer do que se importar com o Cirilo". O olhar da garota volta ao tablet, e o garoto balança a cabeça em incredibilidade.

A cena é muito mais focada na oralidade do que nos elementos visuais e musicais. Percebe-se, pelo diálogo, uma presença constante de apóstrofes, determinando o interlocutor a quem se dirige (no caso, "Maria Joaquina" nas falas de Daniel e "Daniel" nas falas de Maria Joaquina). Essa é uma estratégia de repetição usada para endossar o personagem ao nome que ele carrega, norteando o público a respeito de quem é quem na cena, especialmente aos espectadores que não acompanham a novela desde o início.

Outro fenômeno constante no diálogo são os símbolos. O "coração" é utilizado no lugar dos sentimentos de compaixão e fraternidade que uma pessoa costuma desenvolver por outra - o que não é o caso de Maria Joaquina com relação a Cirilo. Já "Deus" é usado de forma apelativa, como se para convencer a interlocutora de que há uma força sobre-humana que pode castigá-la por pensar de forma tão limitada e preconceituosa.

A presença constante dos primeiros planos, sempre diante de quem está com a vez no discurso, serve, mais uma vez, para reforçar o diálogo e caracterizar o enunciador; trata-se do uso da imagem para referendar o sonoro - aqui, manifestado pela modalidade verbal. Esse recurso estilístico também reforça o posicionamento de Maria Joaquina que, sem se intimidar, expressa sua ojeriza a pessoas negras e de classe baixa.

Dentro da sintaxe do melodrama latino-americano, é comum que se encontrem alegorias nacionais, isto é, elementos que venham firmar a nacionalidade da obra. Em Carrossel, vê-se como um desses momentos a aula em que a professora Helena decide pedir uma produção de texto para os alunos. A única exigência é que seja feito um poema com rimas. Paulo, então, diz que não fará a atividade porque rimar é "para menininhas". Perante a afirmativa do garoto, Helena pergunta para que time ele torce e, sem pestanejar, ele menciona o nome do Palmeiras.

Inusitadamente, a professora profere o primeiro trecho do hino do respectivo time: "Quando surge o alviverde imponente / No gramado em que a luta o aguarda / Sabe bem o que vem pela frente / Que a dureza do prélio não tarda!" (Figura 20). Ela mostra como as palavras "imponente" e "frente", bem como "aguarda" e "tarda", produzem rimas e brinca dizendo que, então, o time para qual o garoto torce é "de menininhas". Cria-se, então, uma discussão na sala quando Jaime diz que o "Timão" é que é "time de macho" e cada um passa a defender sua torcida. 
Figura 20 - Professora Helena canta o hino do Palmeiras em aula sobre rimas

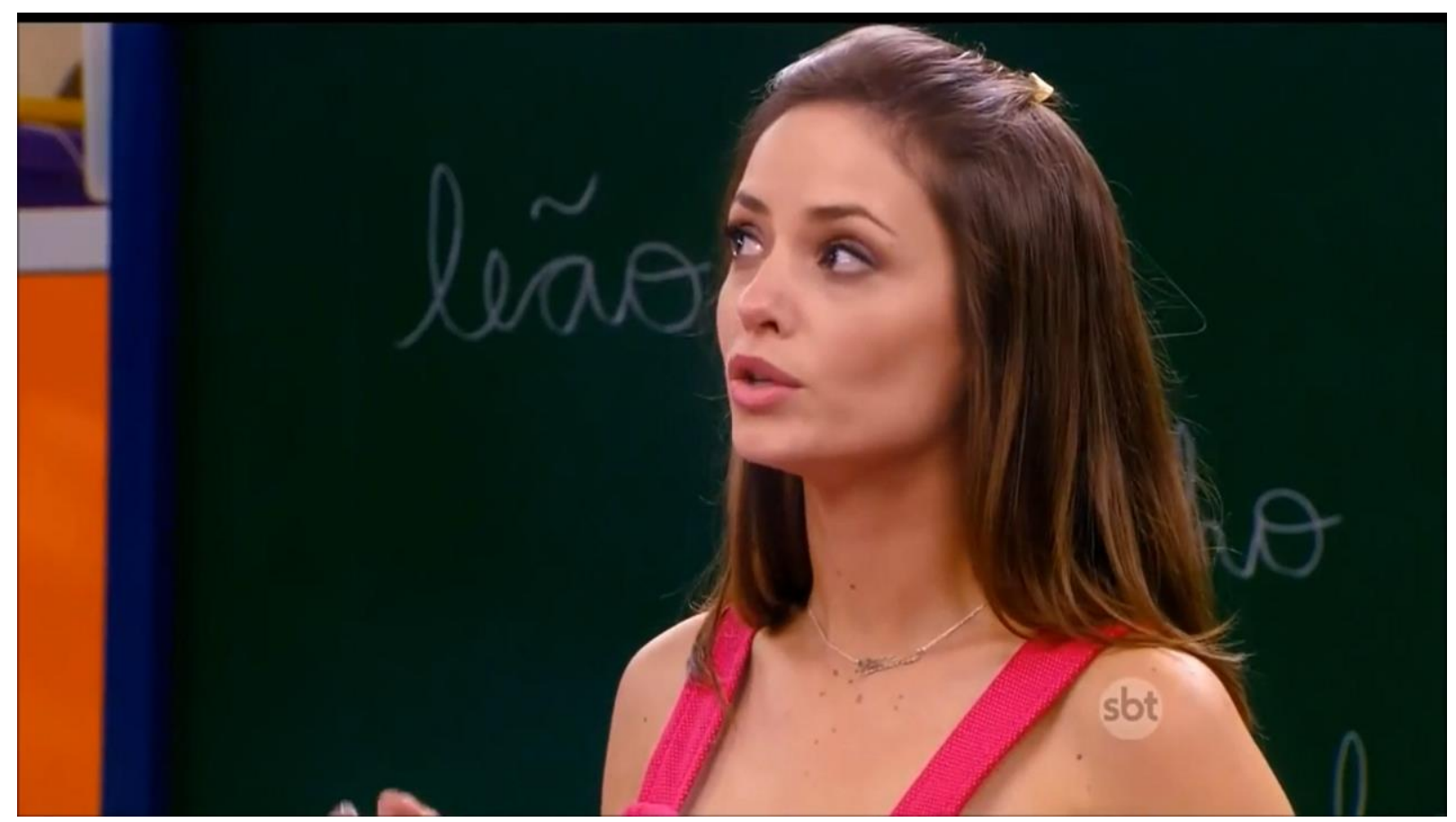

Fonte: Carrossel - capítulo 8. Direção de Reynaldo Boury. São Paulo: SBT, 2012, telev., son., color.

Piadas à parte, o que se percebe é a influência do futebol - talvez a maior alegoria nacional ou, pelo menos, a primeira referência que se tem ao pensar em termos de Brasil - no desenvolvimento da telenovela. Ao mencionar os nomes "Palmeiras" e "Timão" (Corinthians), além da presença da primeira estrofe de um hino, a narrativa constrói um sentido simbólico e se assume brasileira.

Além das alusões ao país de produção, outra característica que se encontra em certos momentos da telenovela é o reforço da identidade, seja por meio dos cenários, seja pela visão kitsch que se consolida. Como maior exemplo, está o momento em que Paulo, ao brincar com Marcelina e Kokimoto, veste-se de Silvio Santos e cria, em seu mundo imaginário, um programa de auditório (Figura 21). 
Figura 21 - Paulo imita Silvio Santos em brincadeira com Kokimoto e Marcelina

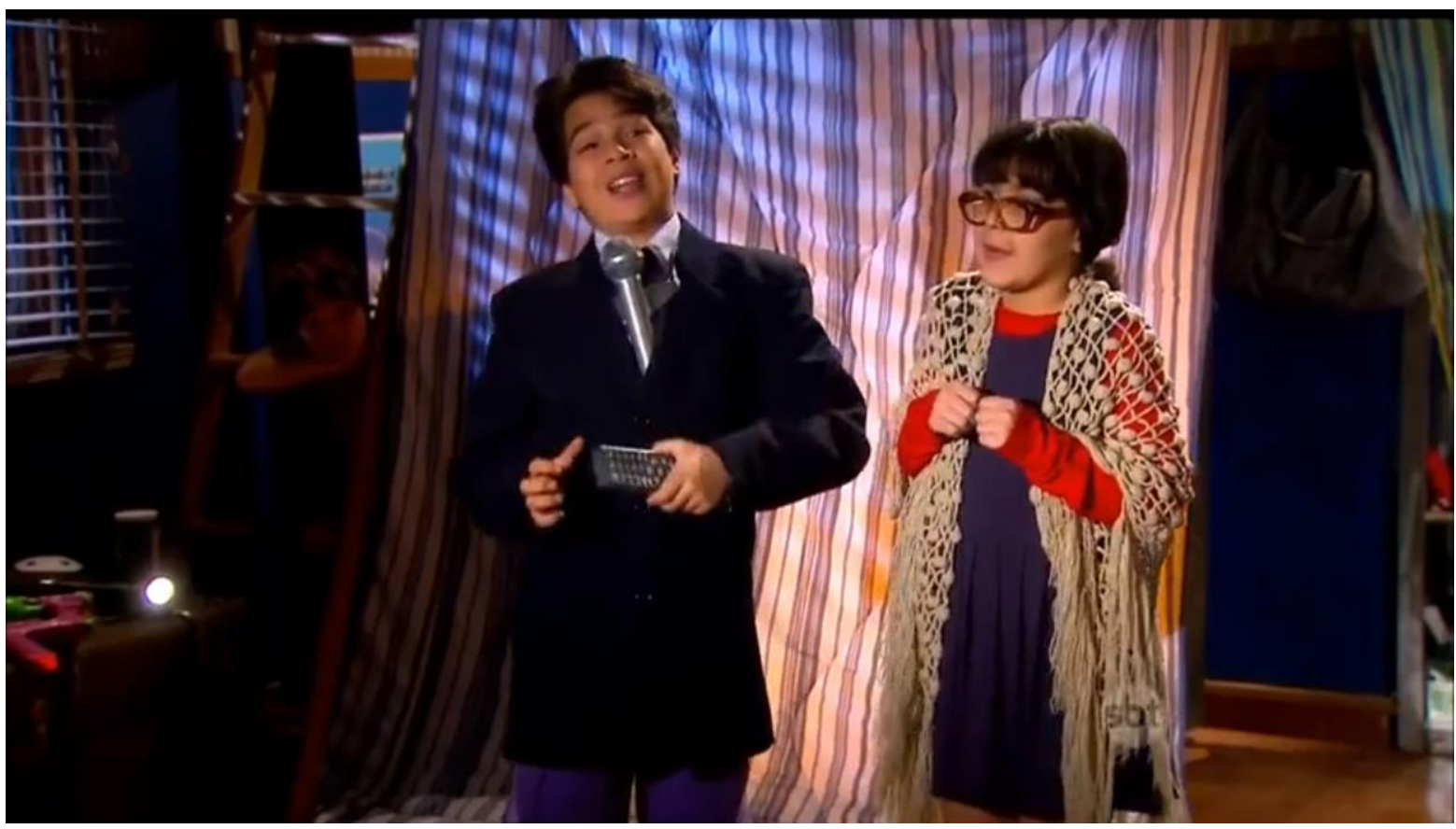

Fonte: Carrossel - capítulo 142. Direção de Reynaldo Boury. São Paulo: SBT, 2012, telev., son., color.

Os programas de auditório são uma marca consagrada do SBT, emissora responsável pela criação de Carrossel, e Silvio Santos, como dono da estação de TV, é o maior ícone que se pode utilizar para fazer menção ao canal. Em outras palavras, ainda que seja de força extremamente lúdica, beirando o jocoso, a assinatura do SBT está impressa na telenovela, muito além da forma de elaborar a narrativa; está também no conteúdo.

A música também tem uma função indispensável para a produção melodramática, sobretudo quando age de forma comandar a narração. Uma cena marcante em Carrossel é o momento em que Cirilo, demonstrando simpatia, quebra seu cofrinho para comprar um buquê a Maria Joaquina. Quando a garota vê que ele conseguiu entrar em sua festa, sente tanta raiva (Figura 22) que amassa as flores na frente do garoto (Figura 23), que mantém o olhar tristonho (Figura 24) e vê a menina jogar no chão o que sobrou do presente (Figura 25). A cena se encerra com um primeiríssimo plano em Cirilo, após Maria Joaquina rejeitá-lo (Figura 26). 
Figura 22 - Maria Joaquina vê Cirilo em sua festa

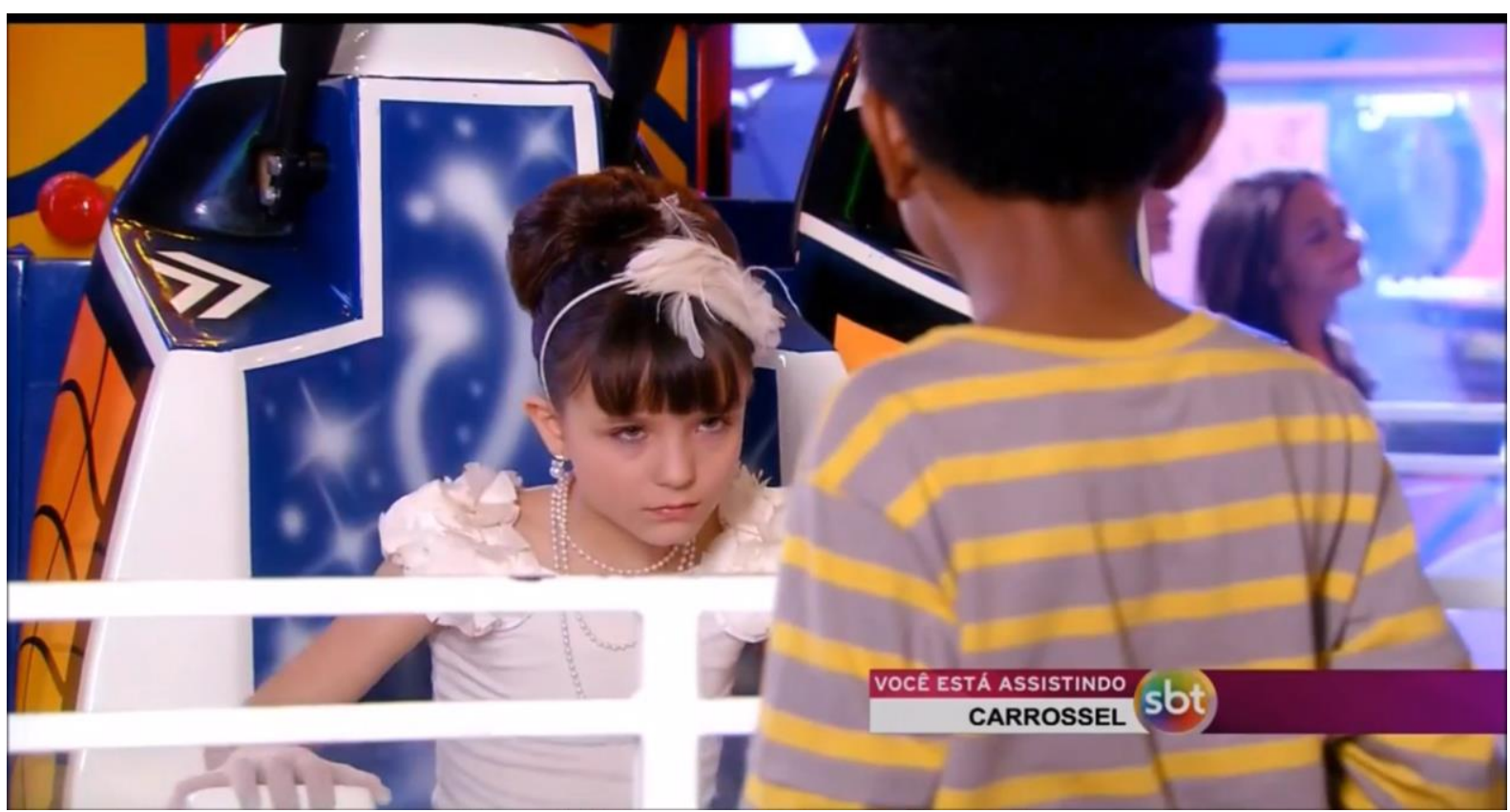

Fonte: Carrossel - capítulo 9. Direção de Reynaldo Boury. São Paulo: SBT, 2012, telev., son., color.

Figura 23 - Maria Joaquina amassa as flores de Cirilo

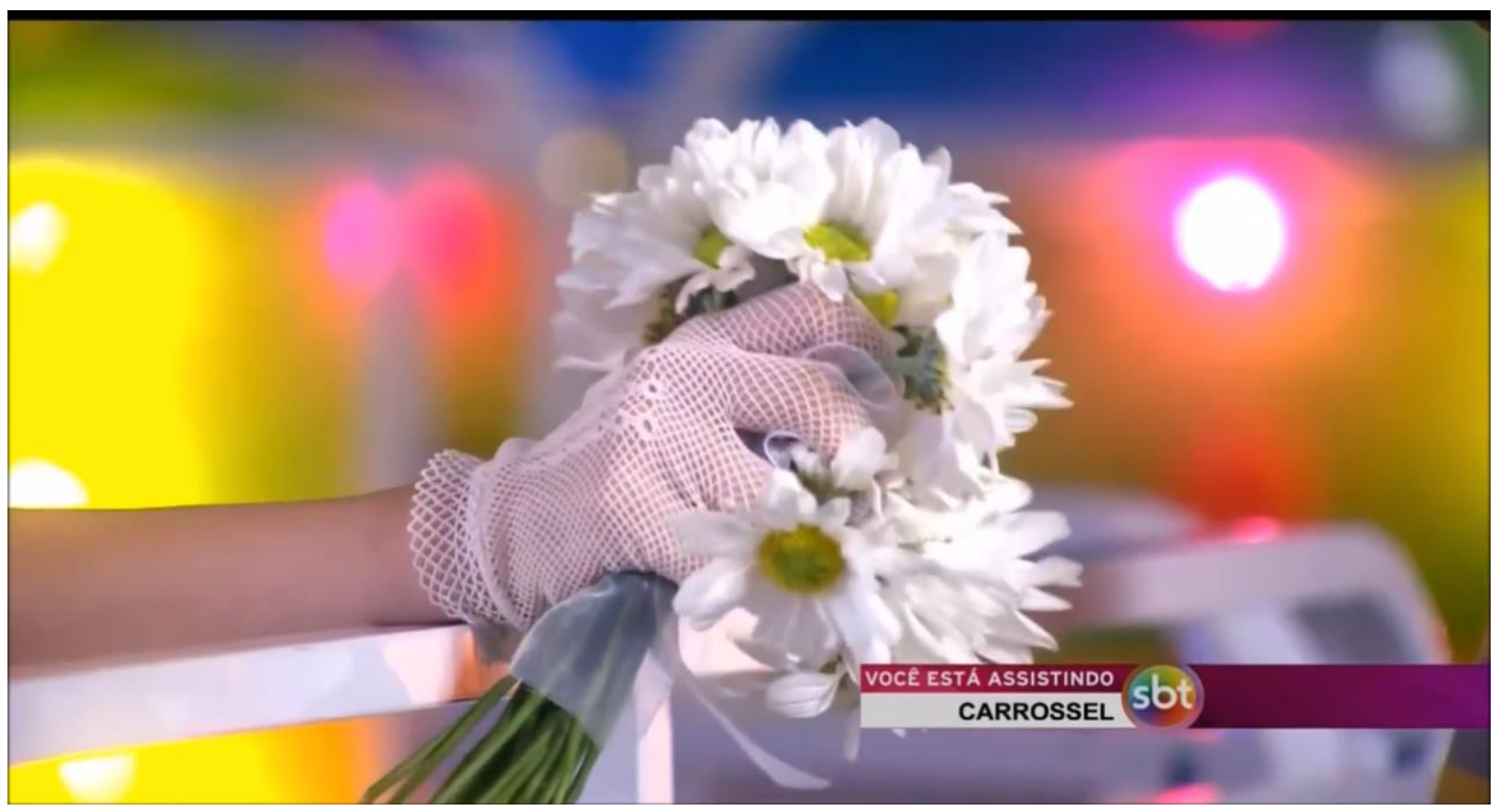

Fonte: Carrossel - capítulo 9. Direção de Reynaldo Boury. São Paulo: SBT, 2012, telev., son., color. 
Figura 24 - Cirilo observa Maria Joaquina destruir o presente

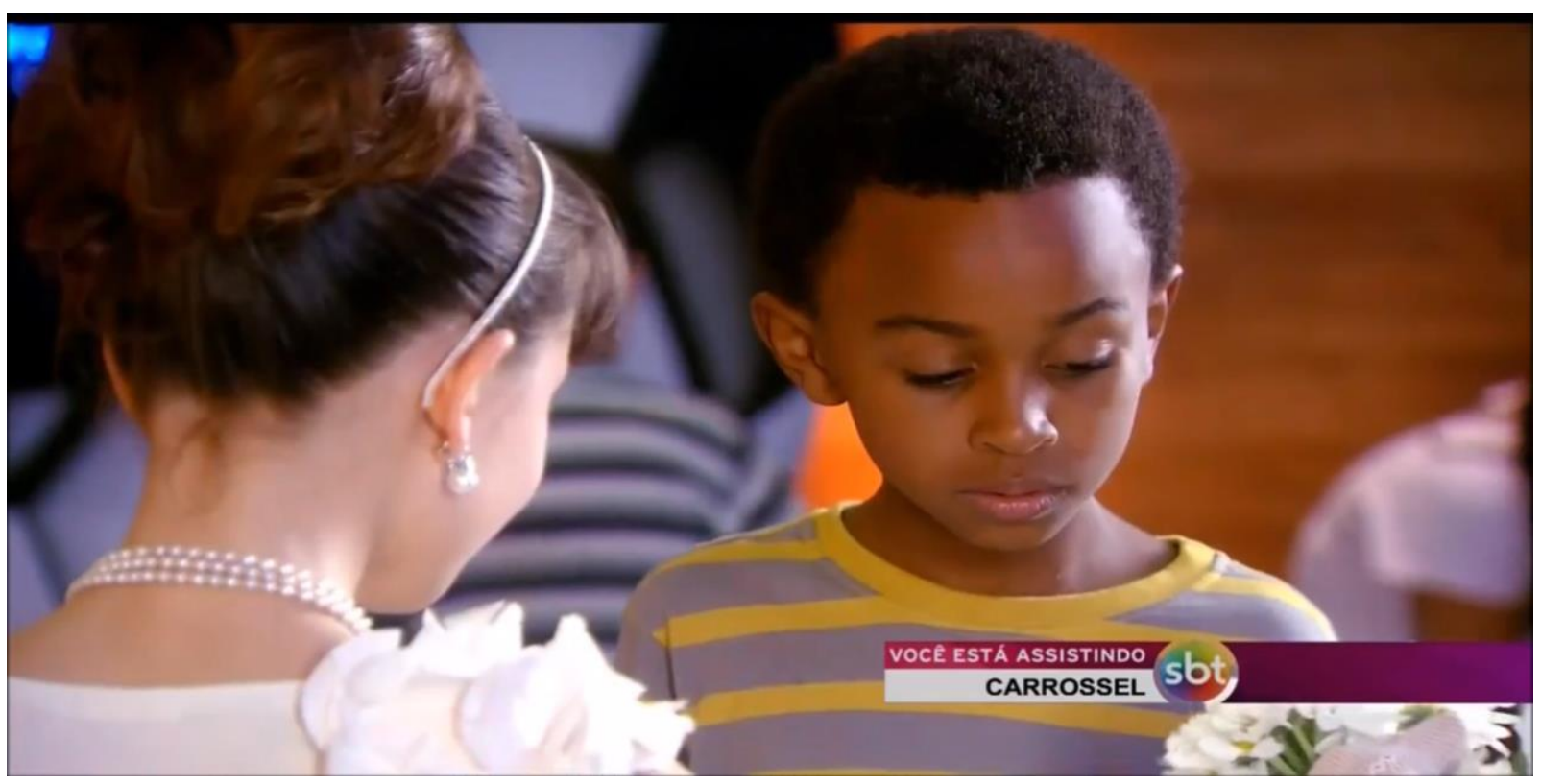

Fonte: Carrossel - capítulo 9. Direção de Reynaldo Boury. São Paulo: SBT, 2012, telev., son., color.

Figura 25 - As flores são arremessadas no chão

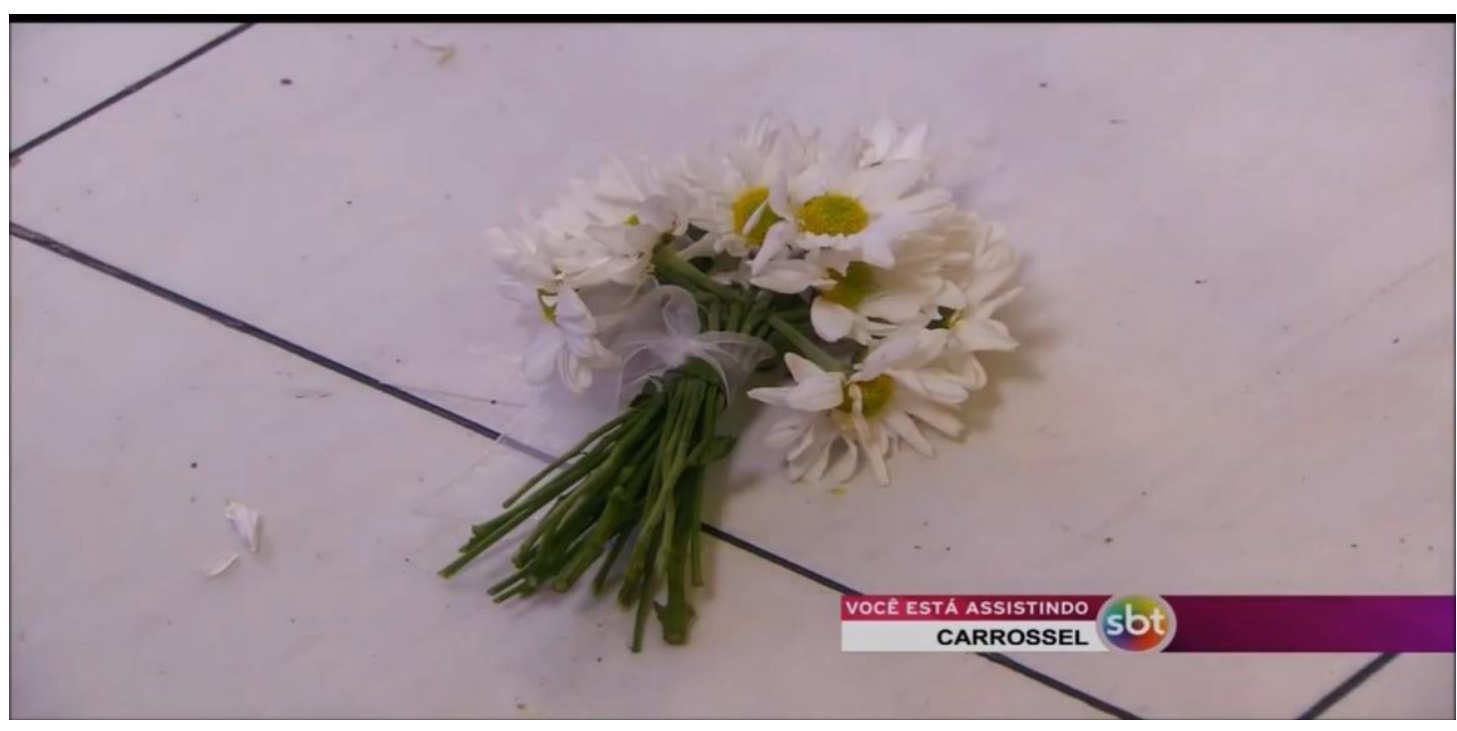

Fonte: Carrossel - capítulo 9. Direção de Reynaldo Boury. São Paulo: SBT, 2012, telev., son., color. 
Figura 26 - Cirilo é rejeitado por Maria Joaquina

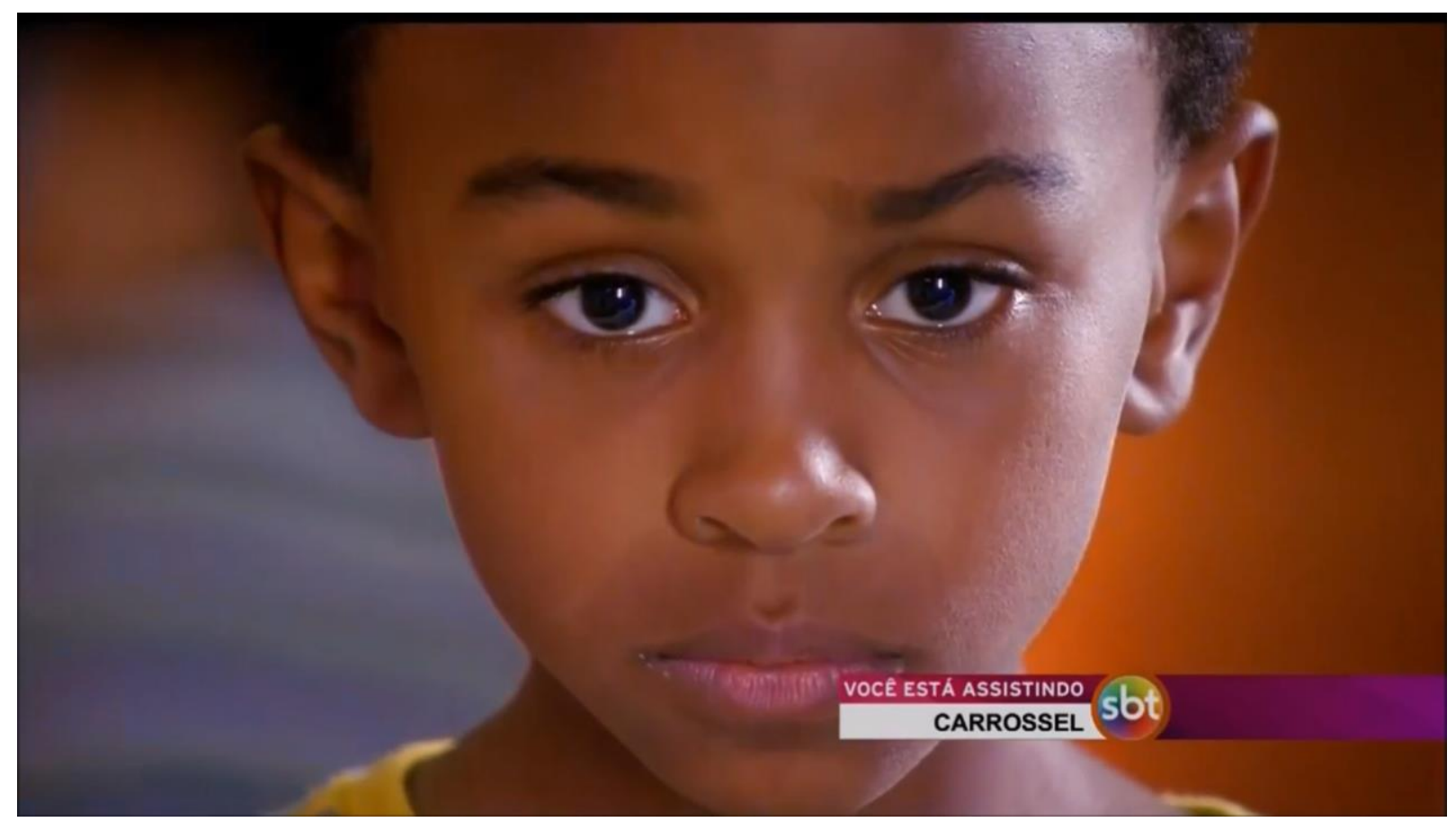

Fonte: Carrossel - capítulo 9. Direção de Reynaldo Boury. São Paulo: SBT, 2012, telev., son., color.

A cena tem o objetivo de ser comovente, tanto que é a mais utilizada em outros programas da emissora e em clipes promocionais como forma de remeter à telenovela, especialmente na relação do casal infantil protagonista. Contudo, o que mais chama a atenção é o fato de não existir suspeita de diálogo: a passagem é firmada nos elementos visuais e recorre à trilha musical para atingir a sensibilidade do espectador. $O$ instrumental Clouds, de Ron Alan Cohen, é praticamente o foco narrativo desse excerto e acentua a natureza melodramática da narrativa.

Outra estratégia do melodrama latino-americano que costuma dispensar o diálogo sem destinar necessariamente a função de narrador à música, é atribuir sentido aos símbolos imagéticos, cabendo a eles a missão de predizer o futuro. Um exemplo disso é a cena em que Helena é caracterizada como paixão de Renê. A luz, o brilho e o vento no cabelo fazem da personagem - que se aproxima num travelling para frente (Figura 27) - o alvo de conquista, além de anunciar ao espectador, sem a menor intenção de suspense, que eles ficarão juntos no final. 
Figura 27 - O rosto de Helena é visto pela primeira vez por Renê

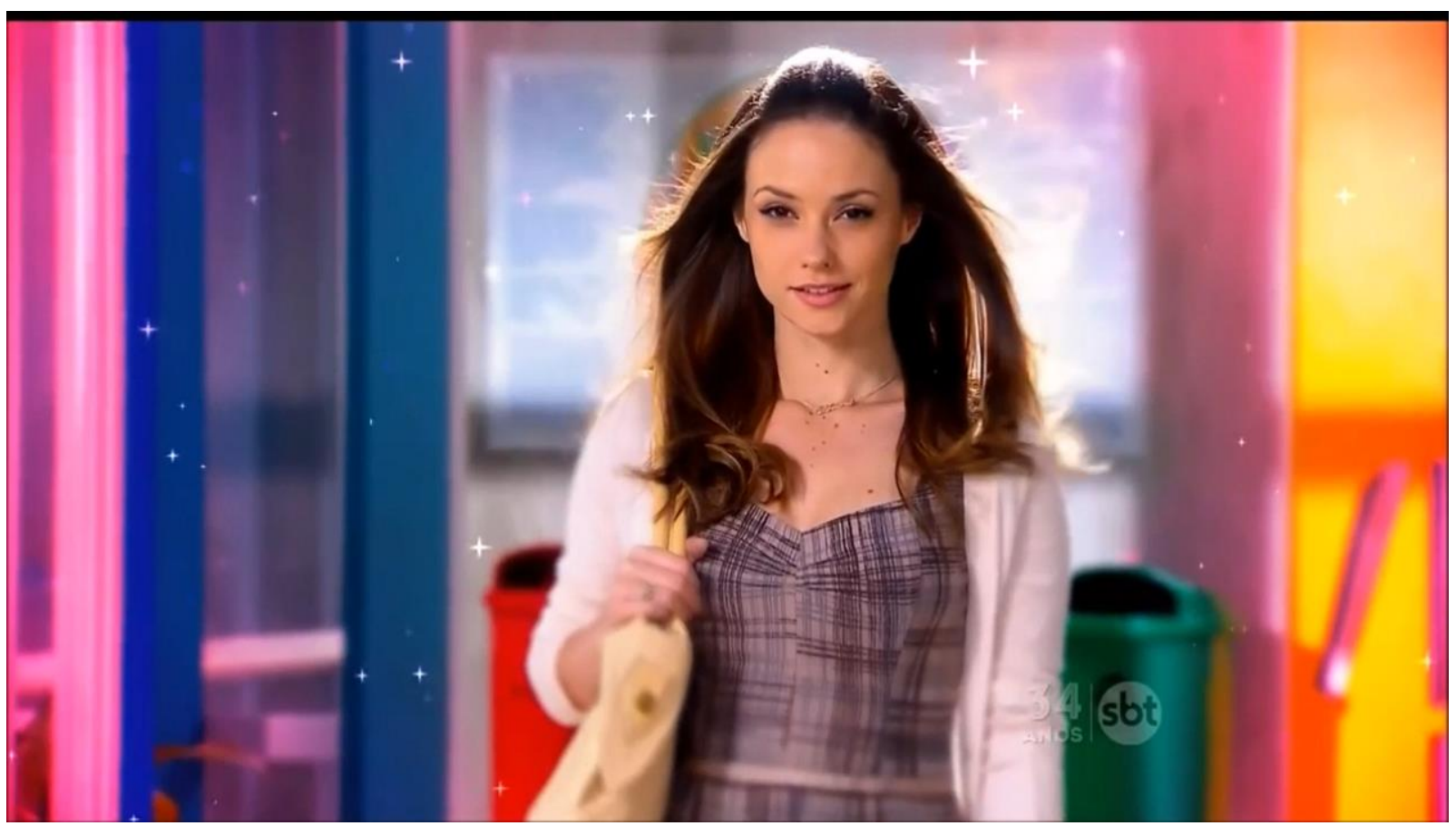

Fonte: Carrossel - capítulo 139. Direção de Reynaldo Boury. São Paulo: SBT, 2012, telev., son., color.

\section{Considerações Finais}

As análises apresentadas neste trabalho apontam que a telepoética do SBT, em se tratando de ficção seriada infantojuvenil, encontra-se calcada no melodrama clássico, em especial na abordagem adotada pelas obras latino-americanas. No recorte estudado, percebemos que a telenovela Carrossel (2012-2013) constrói sua trama em pilares já consagrados da estrutura melodramática, que mesclam conflitos familiares e sociais, pares românticos e situações fatídicas, reforço à identidade nacional e autoral, música com funcionalidade narrativa e imagens emblemáticas.

Em termos de narrativa, a telenovela apresenta uma história com personagens bem delimitados, dos mocinhos aos vilões, em temporalidade e ambientações bem definidas, com linguagem de fácil compreensão, ainda que obedecendo à norma culta da língua portuguesa. Para estabelecimento de casais, usa-se do encantamento, da magia, dos efeitos expressivos que visam ao despertar da ternura, reforçando a máxima do amor à primeira vista, do encontro de almas gêmeas; para as situações fatídicas, por sua vez, exageram-se nos elementos do drama, exacerbando as situações, provocando uma aclamação à melancolia.

Em termos de estilo, a telenovela conta com cores muito vibrantes, enquadramentos geralmente fechados, priorizando os primeiros e primeiríssimos planos, especialmente em situações de conflito ou extravasamento das emoções do personagem. Os figurinos são bastante estereotipados, facilitando na demarcação de cada personagem, e a 
maquiagem tende a ressaltar o sentimento da cena, que acaba endossada pelas atuações. Ainda nesse aspecto dos reforços estilística, a trilha musical e os efeitos sonoros enfatizam a ambiência e tornam-se pleonásticos em variados momentos.

Por fim, as análises aqui registradas são parte de um esforço maior para compreender como se moldam as narrativas e como se compõe o estilo da emissora, por meio de suas obras de entretenimento. Por meio delas, no entanto, ficam evidentes algumas passagens que parecem transcender a linearidade do discurso trivial e atingir um grau considerável de poeticidade. A maneira como é construída a situação de revolta de Maria Joaquina com a presença de Cirilo em sua festa, por exemplo, traz, pelo audiovisual, elementos como metáfora (as flores simbolizando o afeto que o menino gostaria de compartilhar) e metonímia (parte de uma situação global que envolve preconceito racial e de classe).

Registramos, portanto, a necessidade de se investigarem esses elementos do poético, que chamamos de "nuances poéticas", em obras cuja finalidade não seja artística ou literária, mas de entretenimento cotidiano. Tais artifícios da linguagem sugerem que a televisão brasileira, em seu modelo comercial aberto, ainda que focada no público infantojuvenil, tem mais complexidade textual do que as primeiras impressões podem demonstrar.

\section{Referências}

ARISTÓTELES. Poética [séc. IV a.C.]. In: OS PENSADORES. Aristóteles. São Paulo: Nova Cultural, 1999. p. 37-75.

BALLY, Charles. Précis de stylistique: esquisse d'une methode fondée sur I'étude du français moderne. Genebra: A. Eggimann, 1905.

BALLY, Charles. Traité de stylistique française. Paris: Klincksieck, 1909.

BORDWELL, David. Figuras traçadas na luz: a encenação no cinema.

Campinas: Papirus, 2008.

BUTLER, Jeremy G. Television style. Nova Iorque: Routledge, 2010.

BUTLER, Jeremy G. Television: critical methods and applications. 2. ed. Mahwah: Lawrence Erlbaum Associates, 2002.

FROME, Jonathan. Melodrama and the psychology of tears. Projections, Nova Iorque; Oxford, n. 8, v. 1, p. 23-40, 2014. Disponível em: http://goo.gl/py0d60. Acesso em: 22 nov. 2018.

HENRIQUES, Claudio Cezar. Estilística e discurso: estudos produtivos sobre texto e expressividade. Rio de Janeiro: Elsevier, 2011.

HERGESEL, João Paulo. Carrossel de sentimentos: melodrama na telenovela do SBT. Fronteiras: estudos midiáticos, São Leopoldo (RS), v. 19, p. 72-82, 2017. Disponível em: https://goo.gl/mqSpH2. Acesso em: 18 abr. 2019.

HERGESEL, João Paulo; FERRARAZ, Rogério. Melodrama infantojuvenil na televisão brasileira: análise estilística de Carrossel (SBT, 2012-2013). Conexão: 
Comunicação e Cultura, Caxias do Sul (RS), v. 16, n. 31, p. 201-222, 2017. Disponível em: https://goo.gl/qjGKj4. Acesso em: 18 abr. 2019.

LOPES, Maria Immacolata Vassalo de. Telenovela como recurso comunicativo. Matrizes, São Paulo, v. 3, n.1, p. 21-47, 2009. Disponível em: https://goo.gl/34Zd6W. Acesso em: 22 nov. 2018.

MARTÍN-BARBERO, Jesús. Melodrama: o grande espetáculo popular. In: MARTÍNBARBERO, Jesús. Dos meios às mediações: comunicação, cultura e hegemonia. 6. ed. Rio de Janeiro: Editora UFRJ, 2009, p. 163-172.

MOLES, Abraham. O kitsch. 2. ed. São Paulo: Perspectiva, 1975.

OROZ, Silvia. Melodrama: o cinema de lágrimas da América Latina. Rio de Janeiro: Funarte, 1992.

ROCHA, Simone Maria. Estilo televisivo: e sua pertinência para a TV como prática cultural. Florianópolis: Insular, 2016.

ROCHA, Simone Maria; ALVES, Matheus Luiz Couto; OLIVEIRA, Lívia Fernandes. A história através do estilo televisivo I: a Revolta da Vacina na telenovela Lado a Lado. In: ROCHA, Simone Maria. Estilo televisivo: e sua pertinência para a TV como prática cultural. Florianópolis: Insular, 2016. p. 43-64.

SILVA, Karen de Cássia. A [de]formação da infância na sociedade de consumo: o merchandising na telenovela Carrossel do SBT. Dissertação (Mestrado em Educação) - Universidade Federal de São Carlos, 2016. Disponível em:

https://repositorio.ufscar.br/bitstream/handle/ufscar/7696/DissKCS.pdf?sequenc e=1\&isAllowed=y. Acesso em: 22 nov. 2018.

SOUZA, Luzineide Pedrosa de. As relações étnico-raciais nas novelas infantis: Carrossel e Chiquititas. Monografia (Especialização em Educação das Relações Étnico-Raciais) - Núcleo de Estudos Afro-Brasileiros, Universidade Federal do Paraná, 2015. Disponível em: https://acervodigital.ufpr.br/handle/1884/41995. Acesso em: 22 nov. 2018. THOMASSEAU, Jean-Marie. O melodrama. São Paulo: Perspectiva, 2012 THOMPSON, Kristin. Storytelling in Film and Television. Cambridge (Massachusetts); Londres: Harvard University Press, 2003.

TODOROV, Tzvetan. Gramática del Decameron. Madri (Espanha): Taller de Ediciones Josefina Betancor, 1973.

VALENTIM, Lucy Mary Soares. A imagem docente na novela Carrossel apresentada na Argentina, no México e no Brasil: a vocação, o magistério e a indústria cultural. Tese (Doutorado em Educação) Universidade Federal de São Carlos, 2016. Disponível em: https://goo.gl/zsXO8f. Acesso em: 22 nov. 2018. 